\title{
Improving Emergency Department Throughput: Using a Pull Method of Patient Flow
}

Jeffrey Collins

University of St. Augustine for Health Sciences, j.collins2@usa.edu

DOI: https://doi.org/10.46409/sr.CSAP4806

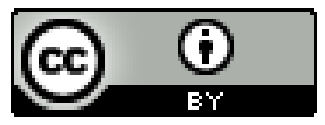

This work is licensed under a Creative Commons Attribution 4.0 License.

Follow this and additional works at: https://soar.usa.edu/scholprojects

Part of the Emergency Medicine Commons, Nursing Administration Commons, and the Quality Improvement Commons

\section{Recommended Citation}

Collins, J. (2021). Improving Emergency Department Throughput: Using a Pull Method of Patient Flow. [Doctoral project, University of St Augustine for Health Sciences]. SOAR @ USA: Student Scholarly Projects Collection. https://doi.org/10.46409/sr.CSAP4806

This Scholarly Project is brought to you for free and open access by the Student Research at SOAR @ USA. It has been accepted for inclusion in Student Scholarly Projects by an authorized administrator of SOAR @ USA. For more information, please contact soar@usa.edu, erobinson@usa.edu. 
Improving Emergency Department Throughput:

Using a Pull Method of Patient Flow

Jeffrey Collins, MSN, RN

School of Nursing, University of St. Augustine for Health Sciences

This Manuscript Partially Fulfills the Requirements for the

Doctor of Nursing Practice Program and is Approved by:

Kathleen Farrell, DNSc, RN

M. Christopher Saslo DNS, ARNP-BC, FAANP

Date of Final Approval written as April 3, 2021 
Abstract

Practice Problem: Overcrowding in the emergency department (ED) has been shown to increase the length of hospital stay, adversely impact patient outcomes, and reduce patient satisfaction. Problems with overcrowding and throughput are often thought of as an EDspecific inefficiency; however, the issue is indicative of hospital-wide inefficiencies.

PICOT: The PICOT question that guided this project was "For ED patients admitted to the medical-surgical unit at an acute medical center, will the implementation of a pull model for patient flow, when compared to the current push model, reduce admission delay and length of stay (LOS) within six weeks of implementation?

Evidence: A total of 21 studies were identified in the literature that directly support the implementation of this project. Themes from the literature include delays adversely impact patients, ED throughput is directly affected by throughput of inpatient units, and bed ahead programs can improve throughput.

Intervention: The primary intervention for this project was implementing a bed ahead process for the host facility. The nurse hand-off process was also altered to improve efficiency.

Outcome: The project resulted in an improvement in the ED delay time. During the project, the mean admission delay time was reduced from 184 minutes to 112 minutes.

Conclusion: Using a pull methodology effectively enhances ED throughput by reducing delays in the ED admission process. 


\section{Improving Emergency Department Throughput: \\ Using Pull Method of Patient Flow}

Extended wait times in the emergency department (ED) negatively impact patient outcomes, staff and patient satisfaction, hospital revenue, and public health outcomes (Zodda \& Underwood, 2019). A major factor of extended wait times in the ED is the delay in processing inpatient admissions, which causes a back log of patients. Unlike other units, the ED has very limited control over patient input. Given the finite number of ED beds available, throughput issues exacerbate the problem of wait times.

This paper describes the development of an evidence-based change project for an acute medical center. The project was designed to improve the throughput, the process of moving patients through the ED in a specific amount of time (DeAnda, 2018). An overview of the practice problem, guiding model and change theory, available evidence, and evidence collection methodologies are included. Additionally, the project setting, plan, and evaluation is described. Finally, the plan for the dissemination of findings is provided.

\section{Significance of the Practice Problem}

The problem of ED overcrowding and reduced throughput has been well-reported in the literature for decades (Lee et al., 2017). Overcrowding in the ED has been shown to increase the length of hospital stay by more than one day (Allaudeen et al., 2017), producing a significantly increased cost in the provision of care.

Problems with throughput are often thought of as an ED-specific inefficiency; however, the issue is indicative of hospital-wide inefficiencies. EDs rely on many other hospital departments to operate efficiently; thus, any measure to improve ED throughput must be approached from a systemic perspective (Kreindler, 2017).

The common metric used to measure ED throughput is the length of stay (LOS), which is the elapsed time for patients between their arrival and their departure (Figure 1). As 
the utilization of the ED has increased sharply in recent years, efficiency has become a top priority for the hospital leadership (Ramsey, 2018). Increased LOS has been shown to negatively impact patient outcomes (Jones et al., 2017; Kawano et al., 2014; Ross et al., 2013; Sharma et al., 2013). Furthermore, increased delays in the ED have been associated with an $11 \%$ increase in costs and a $12 \%$ increase in hospital LOS (Huang et al., 2010).

EDs are not designed to care for patients for extended periods. When delays occur, there is often an adverse impact on both patients and staff (Eriksson et al., 2018). Caring for admitted patients that are held in the ED requires ED nurses to function outside of their area of expertise. The result may be a decreased level of care for both the admitted patient pending placement and the remaining emergency patients and increased work-related stresses on the ED nurse (Wolf et al., 2017).

Metrics for this site are publicly available from the organization, including the admission delay time, which measures the elapsed time from acceptance for admission until the patient departs the ED (Department of Veterans Affairs, 2014). As of the third quarter of the fiscal year 2019, this facility had an average admission delay time of 155 minutes, compared with the benchmark of 61 minutes, set at the national level for all medical centers in the healthcare system (Veterans Health Administration, 2019). The facility had an average ED LOS of slightly over five hours, compared to the national average of just over four hours (Haq et al., 2018). The admission delay time contributes to over half of the ED LOS for this facility.

It is significant to note that during the admission delay time, the patient is in transition between the ED and the admitted unit. Although the emergency treatments have been completed, the inpatient treatments have not been initiated, as the patient has not arrived at the admitted unit.

\section{PICOT Question}


For ED patients admitted to the medical-surgical unit at an acute medical center, will the implementation of a pull model for patient flow, when compared to the current push model, reduce admission delay and LOS within six weeks of implementation?

\section{Population}

The participants of this project were adult patients at an acute medical center, who had been evaluated in the ED and accepted for admission to the medical-surgical unit. Patients were all adults, the majority being male and generally older than 50 years of age.

\section{Intervention}

This intervention was an evidence-based process change that altered the method for bed assignments. The project used a bed ahead concept, which is a pull method used to streamline the movement of patients admitted to the medical-surgical unit based on Lean principles. The Lean concept was developed by Edwards Deming during his industrial engineering work in post-war Japan, adapting the Shewhart Cycle for applications beyond manufacturing (Raja Sreedharan \& Raju, 2016). Creating a bed ahead concept for bed assignments eliminates several steps from the current process, as shown in Figure 2. This proactive change in process has been shown to decrease admission delay time and ED LOS, which has many positive benefits for patients and the staff (Jones et al., 2017; Kawano et al., 2014; Ross et al., 2013; Sharma et al., 2013; Wolf et al., 2017).

\section{Bed Ahead}

At the beginning of each shift, the medical-surgical charge nurse reviewed the available beds and staff workload of the unit. The charge nurse identified the bed and nurse assigned for the next two admissions, repeating the process after each admission to always have at least two bed and nurse combinations identified. This process is highlighted in the project operating procedure approved by the facility leadership (Appendix A). 
The assigned nurses ensured that the assigned beds were cleaned, stocked, and ready for a patient. The charge nurse reported this information to the bed control nurse. When the next admission occured from the ED, the ED nurse notified the bed control nurse, who will notify the next assigned nurse of the admission.

\section{Nurse-to-Nurse Handoffs and Patient Transfer}

The second process change in this operating procedure is to change the flow of the nurse-to-nurse handoff and the actual patient transfer. Upon notification of a pending admission from the bed control nurse, the assigned medical-surgical nurse called the ED nurse to receive report and facilitate the actual patient transfer. The process for physically moving the patient from the ED to the medical-surgical floor changed to align with the pull model. The medical-surgical nurse was responsible for coordinating the transfer, whether completed by the nurse or delegated to a nursing assistant.

\section{Desired State}

The desired state of this project is to create a pull method of patient flow that minimized admission delay times, resulting in a decreased ED LOS. Creating a bed ahead process and improving the nurse-to-nurse handoff procedure may reduce the amount of time needed to move a patient from the ED to the medical-surgical unit. Expediting patient movements to the appropriate inpatient units decreases negative patient outcomes (Leung et al., 2017; McCoy et al., 2015).

\section{Comparison}

In the current push process, several inefficiencies exist that add to the problem of increased admission delay times. Unnecessary calls and missed calls, caused by the push method, are contributors to the increased time needed to transition the patients from the ED to the medical-surgical unit.

\section{Bed Assignment}


In the current push process, as shown in Figure 3, the ED must notify the bed control nurse of the admission, who then calls the medical-surgical charge nurse to obtain a bed assignment. This process often causes delays as the medical-surgical charge nurse must review the current census and staff workload before deciding on the next bed assignment. The medical-surgical charge nurse must then call the bed control nurse with the bed assignment, who, in turn, has to call the ED nurse with the bed assignment. Depending on the workload of the medical-surgical charge nurse, this step can cause delays of up to 45 minutes.

\section{Nurse-to-Nurse Handoff and Patient Transfer}

The current push method of nurse-to-nurse handoff also creates delays that can be mitigated by this project. To provide a handoff report, the ED nurse must call the medicalsurgical nurse. Due to the size of the medical-surgical unit, the physical separation of the four nurses' stations, and the limited availability of telephones on the unit, this often results in another situation requiring a time-wasting return call. Additionally, due to the responsibility of the ED nurse to push the patient through the system, there is little motivation for the medical-surgical nurse to expedite the return call. Consistent with the push methods currently in use, the ED is responsible for physically moving the patient from the ED to the medicalsurgical unit.

\section{Current State}

The current push model introduces several points for delaying the process. As a result, the facility is currently experiencing higher than average admission delay times and ED LOS. A change in the current process is needed to improve patient outcomes, improve patient, and staff satisfaction, as well as reduce the costs associated with extended hospital stays.

\section{Outcome}

The outcome of this project was to decrease both ED LOS and admission delay. The metrics for both are reported in the ED integration software (EDIS) system currently in use at 
the project facility. LOS is reported as the elapsed time in minutes from the time a patient arrives in the ED till when the patient departs the ED (Department of Veterans Affairs, 2014). The admission delay time is the elapsed time in minutes beginning from the time a bed request is made and ending when the patient departs the ED (Department of Veterans Affairs, 2014). The expected outcome of this project was that both times would be reduced by at least 20\%, which was measured with the EDIS system.

\section{Timing}

This project evaluated the outcome measures for six weeks after the project's implementation, compared to the same outcome measures for the six weeks prior to the project implementation. For this project, a collection week started at midnight Monday morning.

\section{Evidence-Based Practice Model and Change Theory}

The Iowa EBP model-revised and Lewin's change theory were used to guide the project. The EBP model and theory are integral in determining the success or failure of a project (Lynch et al., 2018). This project will use Lewin's theory of change as a guiding model. The key steps delineated in Lewin's theory are unfreezing, changing, and refreezing (Wojciechowski et al., 2016). Consistent with the Iowa EBP Model, the project will determine that the topic is a priority for the institution, confirm that there is sufficient evidence to support a system change, and decide if the change is sustainable and appropriate for system-wide adoption (Iowa Model Collaborative et al., 2017).

\section{Evidence-Based Practice Model}

The project will use the Iowa Model-Revised as a guide for the EBP practice change. The Iowa Model was originally developed in the 1990s at the University of Iowa Hospitals and Clinics (UIHC) and College of Nursing to guide the infusion of research findings into practice. The model was revised in 2015 to modernize the guide, accounting for the evolution 
of implementation science since the original publication. In the time between the original model and the revision, the availability of evidence, promotion of EBP, interprofessional collaboration, and the use of electronic data have all increased significantly (Iowa Model Collaborative et al., 2017).

The Iowa Model-Revised (Figure 4) seeks to answer three key questions in the implementation of an EBP practice change: "Is the topic a priority?," "Is there sufficient evidence?," and "Is the change appropriate for adoption in practice?" (Iowa Model Collaborative et al., 2017).

\section{Is the topic a priority?}

Initial discussion with the facility leadership confirmed that the change was needed to improve the throughput of the ED admissions at the facility. This changed aligned with facility goals.

\section{Is there sufficient evidence?}

The project lead performed an exhaustive review, appraisal, and synthesis of the available evidence. The outcome of this review confirmed that there was sufficient evidence to support this change.

\section{Is the change appropriate for adoption in practice?}

The outcome of this project was used to decide if the change is appropriate for permanent adoption by the facility. Upon achieving a successful outcome, the project was submitted to the facility for implementation in a permanent policy change.

\section{Change Theory}

For an EBP change project to have a sustained impact on patient outcomes, not only the process but also the culture needs to be changed. Lewin's theory of change was the guiding theoretical principle for this project. According to Lewin's theory, a change occurs in three steps: unfreezing, change, and refreezing. The unfreezing process begins when the 
problem is identified, which allows employees to recognize the need for change and accept an alternative process. The intervention is implemented in the change step. Lastly, the new process is stabilized and becomes a normal operation in the refreezing step (Wojciechowski et al., 2016).

\section{Unfreezing}

The unfreezing stage of Lewin's theory is where the need for a process change is presented to stakeholders and the reason for the change is established. For this project, the the element that requires change is the length of time required to move patients admitted from the ED to the medical-surgical floor. The process was unfrozen by highlighting the current metrics and inefficiencies in the process to the stakeholders. One of the greatest barriers to overcome with this project was the culture of "We have always done it this way." In unfreezing, the stakeholders were made to see the issues and the potential to improve patient care as well as the possible improvements in the working conditions of the staff.

\section{Change}

The change for this process involved creating a bed ahead protocol of assigning inpatient beds for patients admitted from the ED and altering the process of nurse handoff for ED admissions. This project change was implemented through a facility-approved operating procedure (Appendix A), which altered the admission process.

\section{Refreezing}

Upon successful completion of this project and acceptance by the facility leadership, the improved process was submitted the facility for permanent policy change. Once the process becomes facility policy, its implementation and tracking will be assigned to a standing shared-governance committee, such as the Patient Flow Committee. The assigned committee will be responsible for ensuring the policy is followed and will make monthly 
reports of compliance through the shared-governance committee structure to the Medical Center Director.

\section{Evidence Search Strategy}

Based on the scholarly question, a literature review was conducted by utilizing an electronic search of databases available via the University of St. Augustine (USA) library portal, the ProQuest database, and the PubMed database. Initial search terms included variations of emergency department (ED, ER, emergency room, accident and emergency, A\&E, and A \& E) and bed ahead, bed assignment, pull model, and Lean principles. All searches were limited to those in the English language, published within the time frame of 2015-2020, and peer-reviewed (where applicable).

The Boolean expression of (ED OR ER OR “emergency department” or "emergency room" or "accident and emergency" or "accident \& emergency" or "a\&e" or "a \& e") AND ("bed ahead" OR "bed assignment" OR "pull model” OR "lean principles") AND (inpatient OR admission) was used. This search yielded 174 citations, which were as follows: 5 citations on the USA library, 163 on ProQuest, and 6 on PubMed. The titles and abstracts of the resultant articles were reviewed for relevance to this project according to the following inclusion criteria: (a) interventions involving patient flow from the ED to an inpatient setting, (b) use of Lean principles for patient flow, or (c) improving patient flow in the ED using bed ahead or pull models. The exclusion criterion was any article not related to healthcare. If a study met inclusion criteria, the full text was retrieved and evaluated to determine inclusion. This process resulted in 21 relevant studies.

\section{Evidence Search Results and Evaluation}

Using the search criteria noted above, strong evidence was found to support the PICOT question. Of the 174 studies originally indexed, 102 were excluded for lack of relevance after reviewing the title and abstract. The resultant 72 articles were retrieved in full 
text from various sources: the USA Library, ProQuest, PubMed, or on inter-library loan. After a review of the full text of the articles, 52 were excluded based on a lack of applicability to the current project. A Preferred Reporting Items for Systematic Reviews and Meta-Analyses (PRISMA) diagram is provided in Figure 5.

To effectively translate research into practice, an EBP must effectively appraise and evaluate available literature to determine the overall quality and applicability of the report (Buccheri \& Sharifi, 2017). The remaining 21 studies were examined using the Johns Hopkins Nursing Evidence-Based Practice Model, and the results are shown in Appendix B and $\mathrm{C}$. The evidence supports utilizing a pull method for patient movement and bed ahead protocols to improve patient flow.

\section{Themes from the Evidence}

After a review of the available evidence, multiple themes were discerned from the literature. A summary of the primary evidence can be found in Appendix B, and a summary of the systemic reviews can be found in Appendix C. The main themes that emerged include the ED throughput should be viewed from a facility perspective, output delays lengthen the input wait times, ED delays negatively impact patient outcomes, Lean pull methods improve ED throughput, and bed ahead protocols reduce ED delays.

\section{ED Throughput is a Facility-Wide Issue}

Although ED throughput is viewed as a singular issue of the ED, the literature shows that many factors outside of the ED impact ED throughput. Factors such as radiology turnaround times (Hitti et al., 2017), housekeeping (Melton et al., 2016), and inpatient discharge times (Artenstein et al., 2017) all have a significant impact on ED throughput. Thus, ED throughput is dependent on the efficiencies of the entire facility. These collective efficiencies are reflected in the ED throughput metrics (Walker et al., 2016). 
It is important to understand that the ED does not function in a vacuum, and any significant improvements in throughput metrics require a team approach, relying on actions from across the facility. According to Vashi et al. (2019), integration across department boundaries is a key aspect of the Lean model. It may be difficult for a housekeeper on the medical-surgical unit to understand how their actions impact the length of time for which patients wait in the ED waiting room, but there is an impact. Delays in receiving laboratory results, performing radiographic studies, stocking supplies or medications, and contacting consulting services have a significant impact on ED throughput. All individuals, from housekeepers to doctors, play a significant role in decreasing the admission delay time, and it becomes important to ensure that each participant is aware of their impact on the process of improvement. Lastly, facility leadership must view ED throughput metrics from the facility level, not relying on the ED alone to improve the metrics.

\section{Output Delays Cause Input Delays}

When viewed from a systems standpoint, delays and extended wait times will result anytime the input (patients presenting to the ED) occurs faster than the output (patients discharged) (Kreindler, 2017; Liu et al., 2019). Given that input is often unpredictable, systems must have the built-in capacity and flexibility to absorb surges in patient numbers (McCaughey et al., 2015; Mousavi Isfahani et al., 2019) to provide timely and efficient emergency care. Willard et al. (2017) reported that measures to increase the flow of patients out of the ED significantly decreased the ED LOS.

The data from the facility indicates significant delays during weekdays, between 10:00 a.m. and 6:00 p.m. It is not a coincidence that this is also the time when most hospital discharges occur. The delay in those outputs creates a ripple effect from the medical-surgical unit to the ED waiting room. Given the relatively small capacity of 10 ED beds at this facility, it takes very few output delays to impact the ED throughput and LOS. 


\section{ED Delays Negatively Impact Patient Outcomes}

The issue of ED crowding goes far beyond negatively impacting ED throughput metrics. The evidence indicates that ED delays have a negative impact on patient outcomes. According to McCoy et al. (2015), increased delays in the ED result in postponed treatments, leading to additional LOS in the admitted unit, increased mortality (Leung et al., 2017), and decreased patient satisfaction (DeAnda, 2018; Huang et al., 2018; Rasouli et al., 2019). Increasing ED throughput allows appropriate treatment to begin in a timely manner, which is shown to improve patient outcomes.

It is significant to note how this theme supports the idea that all care provided during the hospital stay has an impact on the overall health outcome of the patient and that healthcare cannot be measured on an individual unit level. The best inpatient care cannot help patients who are delayed in the ED.

By focusing on positive patient outcomes, the facility can increase employees' buy-in of process changes. Showing the relationship between the decrease in ED throughput, increase in-patient mortality, and the cost of healthcare can be a motivating factor for healthcare employees. Whereas, changing a task to simply improve a metric is unlikely to motivate the staff.

\section{Pull Systems Improve ED Throughput}

The use of pull methods has been shown to be beneficial in many industries (Raja Sreedharan \& Raju, 2016). Using pull methods to implement procedures that pull patients to the next area of treatment was found to be beneficial in reducing delays in the ED (Hitti et al., 2017; Improta et al., 2018). Something as simple as pulling a patient for a diagnostic test and admission was shown to reduce ED LOS (Hitti et al., 2017; Melton et al., 2016). The concept of interdepartmental collaboration again highlights the need for a team approach in making 
improvements to ED metrics. Altering a process from a push to a pull method can have a significant impact on ED throughput metrics.

\section{Bed Ahead Process}

Creating a bed ahead process that identifies the next available inpatient bed demonstrates the use of a pull method that reduces delays in ED throughput (Artenstein et al., 2017; Beck et al., 2016; Claret et al., 2016; DiGiacomo et al., 2020; Huang et al., 2018; Mathews \& Long, 2015; Melton et al., 2016). As the bed ahead process occurs proactively, it allows the unit leadership appropriate time to thoroughly evaluate workload prior to the assignment of work, which results in fewer changes compared to assigning work reactively (Melton et al., 2016). The bed ahead concept allows the assigned nurse the opportunity to ensure that the room is cleaned and supplied for the next patient, thereby reducing delays, confusion, and anxiety at the time of admission.

The increased efficiency of a bed ahead model impacts not only patients being admitted to the inpatient service but also those with minor complaints that are treated and discharged from the ED (Huang et al., 2018). The bed ahead model allows more capacity to see patients that would otherwise need to wait due to increased congestion in the ED. While the proactive assignment of beds appears to be a simple solution to a complicated problem, research has shown that a solution does not need to be complex to create a positive impact and solutions that were complex or relied heavily on technology tended to be abandoned before a positive impact could be realized (Chartier et al., 2016). This evidence supports the implementation of a bed ahead process that utilizes a pull method to proactively identify the next available medical-surgical bed to reduce the ED admission delay times.

\section{Nurse Hand-off Procedure}


Altering the nurse hand-off procedure to a pull method will increase the efficiency of patient movements at the facility. Increasing the efficiency of the patient movement will have positive effects on patient outcomes.

\section{Practice Recommendations}

Based on a thorough and rigorous review of the literature using the PICOT question and evidence grading, the themes found through the evidence reveal that using a pull model for creating a bed ahead process and nurse hand-off for admitted patients may result in a reduction in admission delay times in the ED. This reduced delay time has the potential to reduce hospital LOS (McCoy et al., 2015) and improve the quality of care, hospital efficiency, and patient outcomes (Rasouli et al., 2019).

The availability of abundant high-quality evidence, reviewed using the Johns Hopkins Nursing Evidence-Based Practice Model, has revealed that proactively assigning beds for ED admissions results in improved patient outcomes, increased staff and patient satisfaction, and improved quality of care metrics. The outcomes of Lean pull methods, including the bed ahead process, were consistently positive with respect to patient outcomes. No articles reviewed showed a negative outcome for a bed ahead project.

Similar projects have resulted in marked improvements in throughput for patients admitted to the ICU (DiGiacomo et al., 2020), those needing radiographic studies (Hitti et al., 2017), and those admitted to a general ward (Huang et al., 2018). The evidence further supports the use of simple solutions over the use of new technology (Chartier et al., 2016).

With the current practices, the facility fails to meet the current benchmark metrics for ED throughput and falls behind the national average for ED LOS. Improving these measures is a key component of increasing the efficiency of care provided at this facility.

Based on the strength and quality of the evidence, with 19 of 21 articles being graded as good or high quality, supporting this intervention, using a pull model to create a bed ahead 
process, and altering the nurse hand-off process should be implemented to improve ED throughput at this facility.

\section{Project Setting}

This section will describe the project site, including location, organizational need, stakeholders, organizational support, and interprofessional collaboration. An analysis of the strengths, weaknesses, opportunities, and threats is provided.

\section{Description of Project Site}

The setting for this project was a small acute care hospital located in Biloxi, Mississippi. This hospital is part of a healthcare system that offers acute inpatient, primary care, specialty care, mental health, geriatrics and extended care, and a regional blind rehabilitation center. The acute care hospital provides inpatient medical services for patients across the Gulf Coast, including Mississippi, Alabama, and the panhandle of Florida. Through the main campus and four satellite campuses, the total outpatient population served by this healthcare system is approximately 70,000. The acute hospital includes a 10-bed emergency department, a 10-bed ICU, and a 20-bed medical-surgical unit.

\section{Typical Client}

All patients at the healthcare facility are adults, ranging from 18 to geriatric. The majority are male, and all have served in the uniformed services of the United States. The typical client is over age 50 and lives within a 70-mile radius of the facility's main campus.

\section{Mission}

The facility's mission is “To fulfill President Lincoln's promise ‘To care for him who shall have borne the battle, and for his widow, and his orphan' by serving and honoring the men and women who are America's veterans.” (Department of Veterans Affairs, 2020).

\section{Vision}


The facility's vision is “To provide veterans the world-class benefits and services they have earned - and to do so by adhering to the highest standards of compassion, commitment, excellence, professionalism, integrity, accountability, and stewardship.” (Department of Veterans Affairs, 2020).

\section{Leadership Team}

The healthcare system is overseen by a team of five executives (Pentad): the Medical Center Director (MCD), a Chief of Staff (COS), an Associate Medical Center Director (AMCD), an Associate Director for Patient Care Services (ADPCS), and an Associate Director for Outpatient Operations (ADOO). All healthcare system departments report through one of the five Pentad members.

\section{Organizational Need}

The organizational need for this project was established at a meeting with the ADPCS to discuss the current metric data. Based on the facility's metrics, it was determined that currently, there are issues with throughput in the ED. The ADPCS agreed that this need was within the scope of a scholarly, EBP change project. An overview of the project was also discussed with the Chief of Emergency Medicine and ED nurse manager, who also agreed that the project was needed and would benefit the facility.

\section{Stakeholders}

In addition to the leadership team and the patient; the primary stakeholders for the project include the ED nursing and provider staff, the medical-surgical nursing staff, and the bed control nurse. Each stakeholder will play an integral part in the success of this project.

\section{Organizational Support}

To gain organizational support, the project lead met with the MCD, COS, and ADPCS to discuss the project and the potential benefits to the organization and the patients it serves. Each agreed that the project was needed and would increase the quality of care provided by 
the organization. To sustain organizational support, the project lead will provide weekly updates to the team to show the progress of the project and the realized benefits to the facility and patients.

\section{Interprofessional Collaboration}

As this project will alter the processes of multiple units, interprofessional collaboration was needed to complete a successful project. The facility currently has many projects in progress that require working across the boundaries of departments and disciplines. All employees are expected to work in a collaborative and collegial manner to provide the most benefit to the patient population.

\section{SWOT Analysis}

To determine organizational needs, a strengths, weaknesses, opportunities, and threats (SWOT) analysis was conducted, which can be found in Appendix D. The facility shows strengths in stakeholder support, with most employees in the affected units understanding the need for change and willing to undertake projects that improve the quality of care. An active EBP program is currently in place, with employees that are familiar with the process, which will minimize the need to provide training on the EBP model, allowing training time to focus on the new processes. The minimal costs to the facility will assist with gaining organizational support for this project.

The noted potential weakness at the facility includes the reluctance of some employees to participate in new processes. Although a minority, this weakness could create additional work with regard to earning employee buy-in. Some employees are currently working on multiple EBP projects and may feel that they do not have the time to participate in this project. The findings of this exercise indicate that this facility is well equipped to solve this issue. 
The greatest opportunity is the identified focus on the care provided for the patients. The project seeks to make changes that will not only reduce the delay but reduce the negative outcomes caused by the delays. The delays not only impact the health of the patient but also their satisfaction. A byproduct of improving the care and satisfaction of the patient is that the facility will see an improvement in its key quality indicators.

Potential threats include objections from labor partners. The facility labor union has the right to grieve any change in process that they feel negatively impacts the employees. Although labor partners do not tend to object to EBP projects, it is always a possibility. Furthermore, the time needed to make a process changes can be quite lengthy at this facility. All new EBP projects must obtain approval from the facility's EBP committee.

The evaluation indicates that the strengths outweigh its weaknesses. The threats were countered by the opportunity to improve patient care. This process was implemented to adopt a proven process and, thus, improve the patient flow issue.

\section{Project Overview}

This section provides an overview of the project, including the vision, mission, and objectives. An evaluation of risks and risk management plans was discussed.

\section{Project Missions and Vision}

The mission of this project is to improve patient care by reducing admission delay time, in congruence with the facility's strategic goals of quality care, access to care, and excellent patient experience. Reducing the time needed to move the patients from the ED to the medical-surgical unit will improve the quality of care provided at the facility.

The vision of this project is to implement a pull method that will create a bed ahead process facilitating patient transfer, which will alter the way that patients are moved within the facility once they have been accepted for admission. Specifically, this project is expected to result in a $20 \%$ reduction in the admission delay time, from the current 155 minutes. The 
facility currently tracks and reports this metric, which has a national benchmark of 60 minutes.

\section{Project Objectives}

The objective of this project is to improve the throughput in the ED at an acute care hospital. Short-term objectives include improved outcomes that result from shortening admission delays and improving the ED LOS. The long-term objective of this project is to implement a sustained practice change that results in improved patient outcomes.

\section{Risks and Risk Management}

The risks of this project have been assessed and are shown in Appendix E. By design, this project poses minimal risks. The risks were given a score of 1 through 5 based on their probability and potential impact, with 1 being minimal and 5 being severe. The greatest risk posed by this project was a decrease in employee satisfaction. To mitigate this risk, the project lead gathered feedback from the staff and their managers to monitor employee satisfaction.

\section{Project Plan}

Using Lewin's theory as the guiding change theory, this project will unfreeze the process, make needed changes, and then refreeze the process. In conjunction with this change theory, the Iowa EBP Model is utilized as the framework of the project. This section will also discuss the need for interprofessional collaboration, the schedule of activities, budget, leadership plan, and contingency plans.

\section{Unfreezing}

To effect change, this project first demonstrated the need for change. To accomplish this task, the project lead met with staff nurses and discussed the project overview, the current metrics, and the project plan. The project lead worked with the respective nurse managers to identify a group of project champions to assist with the project. This core group 
assisted with unfreezing this process by educating their colleagues on the need for change, communicating issues from the team to the project lead, monitoring the process and the outcomes, encouraging their teams, and providing updates to their teams on the progress.

Concurrently, the opportunity phase of the Iowa EBP Model determined the organizational triggers for the needed change. The champion group analyzed the current process flows to identify any potential needs not addressed by the project.

\section{Change}

The first step of the change phase was to finalize the project plan, using the input from the team to complete and approve the operating procedure. The project plan was reviewed by the Evidence-Based Practice Committee and forwarded for final approval by the ADPCS. With the assistance of the nursing education department, the champion team provided training to the nursing staff on the new process. The project lead ensured that the appropriate communication of the bed ahead assignments was accomplished in accordance with the operating procedure.

The integration phase of the Iowa EBP Model was accomplished by monitoring the admission delay times weekly to evaluate the change. The project was evaluated against the desired state to ensure that the change was having the desired effect. The project was monitored for adherence as the new process flow takes shape.

The piloting phase of the Iowa EBP Model began with the project implementation. In monitoring the processes and their impact on the admission delay times, the project lead and the champion team implemented minor changes based on the feedback gathered from the staff. Each champion was delegated the authority to call for a huddle to discuss any finding they feel is an outlier.

\section{Refreezing}


In the final step of Lewin's model, the new process is solidified or refrozen. The lessons learned in the piloting phase of the Iowa EBP Model were used to make the new process permanent. The project lead will compile the project successes and lessons learned, and this feedback was provided to the key stakeholders and facility leadership.

The sustainment phase of the Iowa EBP Model ensures that the practice change is hardwired into the facility procedures. The champion team monitored the process to ensure the outcomes met the desired state.

Upon completion of this project, the project lead prepared a final presentation for the facility leadership, seeking approval to make the process change permanent. Once policy approval is gained, the operating procedure will be integrated into facility pratcice. Based on current facility policy, the responsibility for monitoring compliance would most likely be transferred to the Patient Flow Committee.

\section{Interprofessional Collaboration}

The success of this project relied on the teamwork of multiple stakeholders in leadership, the ED, nursing operations, and the medical-surgical unit. The project lead first showed the applicability of the project to the facility leadership, then convinced the staff of the benefits of the new process. While explaining the findings available in the literature, the project lead focused on the improved patient outcome and reduced workload on the ED and floor staff.

\section{Schedule of Activities}

The schedule of activities is shown in Appendix F. In the initial phase, the project lead met with the preceptor and advisor to get approval for the project concept. Key stakeholders at the facility were identified, based on their role in the project. They included the ED nurse manager, an ED nurse representative, the medical-surgical nurse manager, a medical-surgical nurse representative, the bed control nurse, and the executive liaison. 
Organizational support was gained by presenting the project to the facility leadership team, who agreed that the change was needed. The stakeholder team provided their input, and the operating procedure was prepared (Appendix A).

\section{Budget}

The projected costs for this project were minimal in comparison to the potential savings. The primary direct costs for this project were the manhours used to train staff nurses in the new process. Training was conducted in 30-minute sessions, with a total of six sessions offered to accommodate staff on all shifts and rotations. A total of 20 ED staff nurses, two bed control nurses, and 24 medical-surgical staff nurses were trained (Table 1). The total estimated cost for training was $\$ 1735$. Given that the host facility annually budgets for training time, this project would not incur any unbudgeted costs. Using an average daily inpatient cost of $\$ 2,000$ per day (Padula et al., 2019). This project would only have to save one inpatient day to break even.

\section{Project Lead Role and Leadership Plan}

It is important to appreciate that this project can only be successful if the frontline staff see it as a viable solution to an actual problem. The leadership philosophy of W. Edwards Deming recognized that employee involvement is key to successful improvement. Deming's teaching highlights that while project leadership is necessary, it cannot replace employee buy-in (Cantiello et al., 2016). This philosophy was instrumental in the manufacturing and business success of Japan throughout the post-war era.

With this understanding, the project lead will facilitate project success by applying Deming's concepts and ensuring that the staff nurses remain engaged throughout the project. The project lead will perform daily huddles with the staff to address issues and concerns. The feedback was used within the Iowa EBP Model to make improvements to the project.

\section{Contingency Plan}


In the event that the host facility needs to limit access to students, due to natural disasters, the pandemic, or other reasons, the project lead and the primary preceptor have arranged to conduct all meetings and presentations remotely using video teleconferencing software. All data collection can be conducted remotely, using existing remote access capabilities. All project participants and stakeholders will have uninterrupted access to the project lead and preceptor. Due to recent events, the facility is well versed in utilizing remote teleconferencing technologies.

\section{Results}

This project evaluated all patient admissions to the medical-surgical unit from the ED, unless otherwise excluded. Exclusion criteria included admissions occurring when all medical-surgical beds were occupied and patients admitted as an overflow to other units or held in the ED. Admissions to other units, including mental health, ICU, operating room, or long-term care were also excluded.

By design, this project underwent continuous evaluation using the Iowa EBP Model. While the Iowa EBP Model allows for agile adjustments to the project, a more formal evaluation and reporting is provided to gauge the success of the project.

\section{Formative Findings}

A formative evaluation took place throughout this project in the form of continuous monitoring of key indicators. These cycles provided the project lead and champion team with the opportunity to monitor the project as the process was changing. The resulting information was used to adjust the process to overcome any obstacles that were discovered. To ensure that the project was progressing toward the desired state, the collected data was analyzed and discussed with the preceptor and facility leadership weekly. Monitoring adherence to the operating procedure and project plan allowed the team to identify issues with the plan, employee engagement, and leadership support. 
The project lead and nursing educators provided the needed training to the bed flow coordinators and the unit charge nurses. The contact information of the project lead was shared with the partcipants in case they needed to discuss any developments with him. In the initial week of the project, all issues were addressed and answers shared with the teams. The project lead monitored the project daily by conducting conducting meetings with project champions, bed flow coordinators, unit leadership. The data collection tools were collected and analyzed daily, with no missed days.

Of significant note to this project, the facility noted a sharp increase in the admission of coronavirus disease (COVID-19) patients in addition to numerous staff members contracting the illness during the project. An additional medical-surgical unit was activated during the project to accommodate the increased number of patients. The added medicalsurgical unit was utilized to primarily handle inter-unit transfers, and any new admissions to this unit were excluded from data collection.

To provide a more encompassing review of the project, a summative evaluation was performed (Ecoff et al., 2020). A formal report of outcomes was presented to the facility leadership.

\section{Summative Findings}

This project initially faced some resistance from staff on both units, which was easily overcome through discussion with the project lead. After the one-week implementation phase, no additional concerns were raised by the staff.

The initial goal of reducing the admission delay time by 20 minutes was met during the project, with the mean admission delay time for the six weeks prior to the implementation of 178.52 minutes being reduced to 155.98 minutes. During the six weeks prior to implementation, a total of 125 admissions were included in the project. During the six weeks of data collection, a total of 97 admissions were included. 


\section{Statistical Analysis}

The statistical analysis was completed in consultation with a statistician. A paired ttest was utilized to analyze the collected data, and the results are shown in Figure 6.

\section{Outcome Measures}

The measures that indicate changes in the outcome of a patient or process are considered outcome measures (Ward et al., 2019). For this project, reducing the admission delay time was the primary goal and is, therefore, viewed as an outcome measure. An additional outcome measure for this project was the ED LOS.

\section{Process Measures}

This project also examined the steps required to create changes in the ED throughput so that the following steps of the project plan could be included. Measures reviewed include the bed request time, notification time, nurse handoff time, and bed assignment time. The results showed that the process was followed in 77 out of 84 shifts for a compliance rate of $91.67 \%$.

\section{Balancing Measures}

Although the goal of the project was to reduce the admission delay time, care was taken to ensure that it did not negatively impact other areas of ED throughput to accomplish this goal. There would be limited value in reducing the admission delay times for patients being admitted to the medical-surgical unit, only to worsen the admission delay times of other units. Balancing measures are meant to indicate the unintended consequences of the project (Ward et al., 2019). The balancing measures, including delays for ICU admission, were captured by the EDIS system and were monitored during the project. No significant impact on balancing measures was found during the project. The financial benefits were not evident in the abbreviated timeframe of this project but will be monitored by the facility for long-term sustainability. 


\section{Financial Measures}

The project was designed to be implemented using minimal capital resources. The project lead closely monitored the training time used for this project, as well as the additional time needed due to the significant alterations in the current process. As labor costs are the largest expense for the facility, any change that increased the time needed for patient care would be a determining factor in the long-term sustainability of this project. No increase in financial resources resulted from this project.

\section{Sustainability}

The improvements demonstrated in this project can be sustained. The simple change of pulling versus pushing patients through the system resulted in a clinically and statistically significant improvement in the admission decision time and the ED LOS. No negative impact on balancing measures was noted. These improvements were realized with no increased utilization of facility resources. After initial concerns, the new process was quickly and easily adopted by both units. The facility will move forward with permanently implementing the process change through a facility policy update.

\section{Data Collection}

Using the data collection tool in Appendix G, the bed control nurse documented the appropriate time for each medical-surgical admission. During shift change, each bed control nurse verified that all times for the shift were documented. The project lead collected the tool each morning. A new form was used for each day, starting at 7:00 a.m.

The project lead reviewed the data collection tool for missing or obvious erroneous data and corrected it as needed. Using an alphanumeric code, known only to the project lead, the ED and accepting providers, and ED and admitting nurse was recorded. This anonymized data was used to identify trends while protecting the employee's privacy. 
To ensure adherence to the project operating procedure, a weekly check sheet (Appendix H) was completed. The medical-surgical charge nurse for each shift completed the check sheet to verify that the required tasks had been completed. This data was monitored daily, and any variance was reviewed with the staff to determine the cause.

\section{Data Analysis}

Data entry occurred daily, with elapsed times shared with the champion team for dissemination to the staff. A weekly report was generated and shared with facility leadership through a video conference with the project lead and preceptor.

\section{Integrity and Validity of Collected Data}

Collected data was verified by the project lead by comparing collected times with the electronic health record (EHR) and EDIS data. Any discrepancy between these times was discussed with the bed control nurse and later reconciled.

\section{Missing and Invalid Data}

The importance of valid data collection cannot be understated. Most data for this project was collected automatically in EDIS, which can be manually verified by reviewing the EHR. The EDIS system has system checks that will not allow certain data errors to occur, such as recording a departure time prior to documenting the admission time. Data collection was reviewed after each shift by the bed control nurse and daily by the project lead. Any missing data was extracted from the EHR.

\section{Team Role in Data Collection}

Multiple team members took part in data collection. The daily admission log was completed by the bed control nurse and the project lead, as indicated in Appendix G. The medical-surgical charge nurse completed the check sheet as shown in Appendix H. The project lead verified that the data collection was completed and accurate.

\section{Evaluation Design}


The project was evaluated by comparing pre- and post-project data, as an evidencebased change project. Certain other identified contributing factors to the admission delay, such as timeliness of nurse reporting (Appendix G) were also evaluated as part of the project as a percentage of compliance.

\section{Data Collection Tool}

The data collection tools for this project have been provided in Appendix G and Appendix $\mathrm{H}$. These forms are simplistic in design, to eliminate the need for extensive training. The simple design also increased the likelihood of the forms being filled out correctly, increasing the validity of the collected data. To ensure the face validity of the data collection tool, the project lead provided an orientation for each user with a return demonstration.

\section{Statistically Significant and Clinically Meaningful Improvement}

As the primary analysis was conducted on pre- and post- elapsed time, a paired t-test was used. The dependent variable (elapsed time) is a ratio measure. A p-value of 0.05 was used to determine a statistically significant change. A reduction in the admission delay time and ED LOS of a minimum of 20 minutes was considered clinically significant. Analysis occurred weekly, with daily observations and feedback provided to the staff. A percentage was calculated for the operating plan utilization and compliance.

\section{Protection of Human Rights and Privacy}

The identities of the employees were anonymized and assigned a unique alphanumeric identifier by the project lead. No identifying patient information was collected, stored, or analyzed.

All data was stored electronically on a secured network, in a restricted network folder accessible only to the project lead and the facility preceptor. All facility networks are secured by a two-step authentication procedure that requires both a Personal Identity Verification 
(PIV) card and a corresponding password. Network folders were restricted to allow access only to selected users. Additionally, all documents, data sets, spreadsheets, and presentations were password protected.

\section{Impact}

The goal of this project was to address the issue of ED throughput. There are many factors outside of this project that also impact ED throughput, but this project focused on the specific issue of the delay time between the time of the patient's acceptance by the admitting physician and the time a patient departed the ED. The project had a positive clinical impact on the admission delay times for patients admitted to the medical-surgical unit from the ED. During the project, the mean admission delay time was reduced from 184 minutes to 112 minutes, as shown in Figure 6. Additionally, ED LOS was reduced from 378 minutes to 261 minutes during the project.

The primary action of this project was to alter the process of admitting and moving patients between the ED and the medical-surgical unit. Additionally, this project increased the awareness of the importance of efficient patient flow in the facility. The project reinforced the concept that ED throughput is a facility-wide issue and is not specific to the ED. Using the available evidence, the medical-surgical nurses were able to see how their actions affected the care the patients received.

By design, this project focused on a very specific subset of patients, those admitted to the medical-surgical unit. The concept could be applied to other units at the facility, including the ICU and behavioral health units, although modifications would be necessary for the different needs of patients admitted to these units.

This project focused on a limited factor in ED throughput. Continued improvements are needed to increase the overall efficiency of emergency care. Some of these factors include 
improving the time needed for diagnostic testing, improving admission decision times, and better efficiency in placing appropriate admission orders in the EHR.

To sustain the improvements realized in this project, the facility will incorporate process changes to include the bed ahead process and an improved nurse hand-off for admitted patients. The process will be monitored by the appropriate self-governance committee to ensure continued success.

\section{Plans for Dissemination}

The project lead prepared a formal paper with the outcomes of this project. The document was submitted to multiple doctoral peers for feedback and review. The results of this peer review were incorporated in the abstracts, presentations, and the manuscript for the project.

The results of this project were presented to the facility leadership, in addition to the shared-governance committees that oversee ED throughput. The presentation to the facility leadership occurred during the regularly scheduled monthly leadership meeting, as all facility service chiefs attend this meeting. The project lead prepared a slide presentation with project outcomes and specific recommendations to sustain improvements. An informative handout with the guiding evidence, PICOT question, pre- and post-throughput results, and an overview of project methods was provided. A poster with an overview of the problem and how this project improved the patient outcomes was created and displayed at all presentations. A question-and-answer session was conducted to encourage further discussion and gain feedback from the groups. Similar presentations and handouts were prepared and shared with the Patient Flow and Evidence Base Practice Committees.

In addition to internal dissemination, a manuscript was prepared and will be submitted to the peer-reviewed journal, the Journal of Emergency Nursing. This journal is widely used in the field of emergency nursing. The project outcomes will be submitted to national nursing 
conferences or virtual equivalents, including the Emergency Nurses Association and the National Evidence-Based Practice Conference. Additionally, the manuscript will be archived in the ScholarWorks Open Access Repository (SOAR).

\section{Conclusion}

The intent of this project was to streamline the bed assignment process to increase efficiencies, reduced workload, improved patient and employee satisfaction, and result in an overall improvement in ED capacity. Using a pull method for patient movement was a key step in improving patient outcomes, timeliness of emergency service, and meeting the national benchmarks for ED throughput. In addition, the project has the potential to improve outcomes for patients admitted to the medical-surgical ward by reducing delays in the admission process. This project required no infrastructure changes, increases in staffing, nor significant capital resources. The implementation of this project will bring some muchneeded improvement, with minimal risks and no additional costs. 


\section{References}

Allaudeen, N., Vashi, A., Breckenridge, J. S., Haji-Sheikhi, F., Wagner, S., Posley, K. A., \& Asch, S. M. (2017). Using Lean management to reduce emergency department length of stay for medicine admissions. Quality Management in Health Care, 26(2), 91-96. https://doi.org/10.1097/QMH.0000000000000132, PubMed: 28375955

Artenstein, A. W., Rathlev, N. K., Neal, D., Townsend, V., Vemula, M., Goldlust, S.,...Tuomi, M. (2017). Decreasing emergency department walkout rate and boarding hours by improving inpatient length of stay. Western Journal of Emergency Medicine, 18(6), 982-992. https://doi.org/10.5811/westjem.2017.7.34663, PubMed: $\underline{29085527}$

Beck, M. J., Okerblom, D., Kumar, A., Bandyopadhyay, S., \& Scalzi, L. V. (2016). Lean intervention improves patient discharge times, improves emergency department throughput and reduces congestion. Hospital Practice, 44(5), 252-259. https://doi.org/10.1080/21548331.2016.1254559, PubMed: 27791449

Buccheri, R. K., \& Sharifi, C. (2017). Critical appraisal tools and reporting guidelines for evidence-based practice. Worldviews on Evidence-Based Nursing, 14(6), 463-472. https://doi.org/10.1111/wvn.12258, PubMed: 28898556

Cantiello, J., Kitsantas, P., Moncada, S., \& Abdul, S. (2016). The evolution of quality improvement in healthcare: Patient-centered care and health information technology applications. Journal of Hospital Administration, 5(2), 62-68.

https://doi.org/10.5430/jha.v5n2p62

Chartier, L. B., Simoes, L., Kuipers, M., \& McGovern, B. (2016). Improving emergency department flow through optimized bed utilization. BMJ Quality Improvement Reports, 5(1), u206156-w2532. https://doi.org/10.1136/bmjquality.u206156.w2532, PubMed: 27752312 
Claret, P. G., Boudemaghe, T., Bobbia, X., Stowell, A., Miard, É., Sebbane, M., . . De La Coussaye, J. E. (2016). Consequences for overcrowding in the emergency room of a change in bed management policy on available in-hospital beds. Australian Health Review, 40(4), 466-472. https://doi.org/10.1071/AH15088, PubMed: 26476497

DeAnda, R. (2018). Stop the bottleneck: Improving patient throughput in the emergency department. Journal of Emergency Nursing, 44(6), 582-588. https://doi.org/10.1016/j.jen.2018.05.002, PubMed: 29935944

Department of Veterans Affairs (2014). Emergency Department integration software (EDIS) user guide. https://www.va.gov/vdl/documents/Clinical/Emergency_Dept_Integration_Software/e dis_2_1_2_ug.doc

Department of Veterans Affairs (2020). About VA. https://www.va.gov/about_va/

DiGiacomo, J. C., Angus, L. D. G., Wallace, R., Cardozo-Stolberg, S., Gerber, N., Munnangi, S.,. . Skarka, K. (2020). The impact of an ICU "bed ahead" policy on ED length of stay and patient outcomes. Annals of Surgery, 271(2), 303-310.

https://doi.org/10.1097/SLA.0000000000002832, PubMed: 29794844

Ecoff, L., Stichler, J. F., \& Davidson, J. E. (2020). Design, implementation and evaluation of a regional evidence-based practice institute. Applied Nursing Research, 55, 151300. https://doi.org/10.1016/j.apnr.2020.151300, PubMed: $\underline{32563672}$

Eriksson, J., Gellerstedt, L., Hilleras, P., \& Craftman, A. G. (2018). Registered nurses' perceptions of safe care in overcrowded emergency departments. Journal of Clinical Nursing, 27(5-6), 1061. https://doi.org/10.1111/jocn.14143

Haq, N., Stewart-Corral, R., Hamrock, E., Perin, J., \& Khaliq, W. (2018). Emergency department throughput: An intervention. Internal and Emergency Medicine, 13(6), 923-931. https://doi.org/10.1007/s11739-018-1786-1, PubMed: 29335822 
Hitti, E. A., El-Eid, G. R., Tamim, H., Saleh, R., Saliba, M., \& Naffaa, L. (2017). Improving emergency department radiology transportation time: A successful implementation of lean methodology. BMC Health Services Research, 17(1), 625. https://doi.org/10.1186/s12913-017-2488-5, PubMed: 28870249

Huang, Q., Thind, A., Dreyer, J. F., \& Zaric, G. S. (2018). The impact of delays to admission from the emergency department on inpatient outcomes. BMC Emergency Medicine, 10(1), 16. https://doi.org/10.1186/1471-227X-10-16, PubMed: 20618934 Improta, G., Romano, M., Di Cicco, M. V., Ferraro, A., Borrelli, A., Verdoliva, C., . . . Cesarelli, M. (2018). Lean thinking to improve emergency department throughput at AORN Cardarelli Hospital. BMC Health Services Research, 18(1), 914. https://doi.org/10.1186/s12913-018-3654-0, PubMed: 30509286

Iowa Model Collaborative, Buckwalter, K. C., Cullen, L., Hanrahan, K., Kleiber, C., McCarthy, A. M., Rakel, B., Steelman, V., Tripp, R. T., \& Tucker, S. Authored on behalf of the Iowa Model Collaborative (2017). Iowa model of evidence-based practice: Revisions and validation. Worldviews on Evidence-Based Nursing, 14(3), 175-182. https://doi.org/10.1111/wvn.12223, PubMed: 28632931

Jones, P., Wells, S., Harper, A., Le Fevre, J., Stewart, J., Curtis, E.,. . Ameratunga, S. (2017). Impact of a national time target for ED length of stay on patient outcomes. New Zealand Medical Journal, 130(1455), 15-34. http://www.nzma.org.nz/journal/readthe-journal/all-issues/2010-2019/2017/vol-130-no-1455-12-may-2017/7239. PubMed: $\underline{28494475}$

Kawano, T., Nishiyama, K., \& Hayashi, H. (2014). Execution of diagnostic testing has a stronger effect on emergency department crowding than other common factors: A cross-sectional study. PLOS ONE, 9(10), e108447. https://doi.org/10.1371/journal.pone.0108447, PubMed: 25310089 
Kreindler, S. A. (2017). The three paradoxes of patient flow: An explanatory case study. BMC Health Services Research, 17(1), 481. https://doi.org/10.1186/s12913017-2416-8, PubMed: $\underline{28701232}$

Lee, I. H., Chen, C. T., Lee, Y. T., Hsu, Y. S., Lu, C. L., Huang, H. H.,. . Yang, U. C. (2017). A new strategy for emergency department crowding: High-turnover utility bed intervention. Journal of the Chinese Medical Association, 80(5), 297-302. https://doi.org/10.1016/j.jcma.2016.11.002, PubMed: 28202338

Leung, A. K., Whatley, S. D., Gao, D., \& Duic, M. (2017). Impact of process improvements on measures of emergency department efficiency. Journal of the Canadian Association of Emergency Physicians, 19(2), 96-105. https://doi.org/10.1017/cem.2016.382, PubMed: 27748221

Liu, A., Kline, D. M., Brock, G. N., \& Bonsu, B. K. (2019). Multistate model of the patient flow process in the pediatric emergency department. PLOS ONE, 14(7), e0219514. https://doi.org/10.1371/journal.pone.0219514, PubMed: $\underline{31291345}$

Lynch, E. A., Mudge, A., Knowles, S., Kitson, A. L., Hunter, S. C., \& Harvey, G. (2018). "There is nothing so practical as a good theory": A pragmatic guide for selecting theoretical approaches for implementation projects. BMC Health Services Research, 18(1), 857. https://doi.org/10.1186/s12913-018-3671-z, PubMed: 30428882 Mathews, K. S., \& Long, E. F. (2015). A conceptual framework for improving critical care patient flow and bed use. Annals of the American Thoracic Society, 12(6), 886-894, E1-E14. https://doi.org/10.1513/AnnalsATS.201409-419OC, PubMed: 25822477

McCaughey, D., Erwin, C. O., \& DelliFraine, J. L. (2015). Improving capacity management in the emergency department: A review of the literature, 2000-2012. Journal of Healthcare Management/American College of Healthcare Executives, 60(1), 63-75. 
https://journals.lww.com/jhmonline. https://doi.org/10.1097/00115514-20150100000011, PubMed: 26529995

McCoy, J. V., Gale, A. R., Sunderram, J., Ohman-Strickland, P. A., \& Eisenstein, R. M. (2015). Reduced hospital duration of stay associated with revised emergency department-intensive care unit admission policy: A before and after study. Journal of Emergency Medicine, 49(6), 893-900. https://doi.org/10.1016/j.jemermed.2015.06.067, PubMed: 26409680

Melton III, J. D., Blind, F., Hall, A. B., Leckie, M., \& Novotny, A. (2016). Impact of a hospitalwide quality improvement initiative on emergency department throughput and crowding measures. Joint Commission Journal on Quality and Patient Safety, 42(12), 533-542. https://doi.org/10.1016/S1553-7250(16)30104-0, PubMed: 28334556

Moher, D., Liberati, A., Tetzlaff, J., Altman, D. G., \& PRISMA Group (2010). Preferred reporting items for systematic reviews and meta-analyses: The PRISMA statement. International Journal of Surgery, 8(5), 336-341. https://doi.org/10.1016/j.ijsu.2010.02.007, PubMed: 20171303

Mousavi Isfahani, H., Tourani, S., \& Seyedin, H. (2019). Lean management approach in hospitals: A systematic review. International Journal of Lean Six Sigma, 10(1), 161188. https://doi.org/10.1108/IJLSS-05-2017-0051

Padula, W. V., Pronovost, P. J., Makic, M. B. F., Wald, H. L., Moran, D., Mishra, M. K., \& Meltzer, D. O. (2019). Value of hospital resources for effective pressure injury prevention: A cost-effectiveness analysis. BMJ Quality and Safety, 28(2), 132-141. https://doi.org/10.1136/bmjqs-2017-007505, PubMed: $\underline{30097490}$

Raja Sreedharan, V., \& Raju, R. (2016). A systematic literature review of Lean Six Sigma in different industries. International Journal of Lean Six Sigma, 7(4), 430-466. https://doi.org/10.1108/IJLSS-12-2015-0050 
Ramsey, Z., Palter, J. S., Hardwick, J., Moskoff, J., Christian, E. L., \& Bailitz, J. (2018). Decreased nursing staffing adversely affects emergency department throughput metrics. Western Journal of Emergency Medicine, 19(3), 496-500. https://doi.org/10.5811/westjem.2018.1.36327, PubMed: 29760847

Rasouli, H. R., Esfahani, A. A., Nobakht, M., Eskandari, M., Mahmoodi, S., Goodarzi, H., \& Abbasi Farajzadeh, M. (2019). Outcomes of crowding in emergency departments: A systematic review. Archives of Academic Emergency Medicine, 7(1), e52. http://journals.sbmu.ac.ir/aaem. PubMed: $\underline{31602435}$

Ross, M. A., Hockenberry, J. M., Mutter, R., Barrett, M., Wheatley, M., \& Pitts, S. R. (2013). Protocol-driven emergency department observation units offer savings, shorter stays, and reduced admissions. Health Affairs, 32(12), 2149-2156. https://www.healthaffairs.org/journal/hlthaffhttps://doi.org/10.1377/hlthaff.2013.0662 , PubMed: 24301399

Sharma, R., Mulcare, M. R., Graetz, R., Greenwald, P. W., Mustalish, A. C., Miluszusky, B., \& Flomenbaum, N. E. (2013). Improving front-end flow in an urban academic medical center emergency department: The emergency department discharge facilitator team. Journal of Urban Health: Bulletin of the New York Academy of Medicine, 90(3), 406-411. https://doi.org/10.1007/s11524-012-9752-0, PubMed: $\underline{22875541}$

Vashi, A. A., Lerner, B., Urech, T. H., Asch, S. M., \& Charns, M. P. (2019). Lean enterprise transformation in VA: A national evaluation framework and study protocol. $B M C$ Health Services Research, 19(1), 98. https://doi.org/10.1186/s12913-019-3919-2, PubMed: $\underline{30717729}$ 
Veterans Health Administration (2019). Strategic analytics for improvement and learning (SAIL). https://www.va.gov/QUALITYOFCARE/SAIL_FY19_Q3/SAIL16_gulfcoastHCS_fy19q3.xls

Walker, C., Kappus, K., \& Hall, N. (2016). Strategies for improving patient throughput in an acute care setting resulting in improved outcomes: A systematic review. Nursing Economics, 34(6), 277-288. http://www.nursingeconomics.net/cgibin/WebObjects/NECJournal.woa. PubMed: $\underline{29975490}$

Ward, M. E., Wakai, A., McDowell, R., Boland, F., Coughlan, E., Hamza, M., ... and McAuliffe, E. (2019). Developing outcome, process and balancing measures for an emergency department longitudinal patient monitoring system using a modified Delphi. BMC Emergency Medicine, 19(1), 7. https://doi.org/10.1186/s12873-0180220-3, PubMed: $\underline{30642263}$

Willard, E., Carlton, E. F., Moffat, L., \& Barth, B. E. (2017). A full-capacity protocol allows for increased emergency patient volume and hospital admissions. Journal of Emergency Nursing, 43(5), 413-418. https://doi.org/10.1016/j.jen.2017.01.007, PubMed: $\underline{28456336}$

Wojciechowski, E., Pearsall, T., Murphy, P., \& French, E. (2016). A case review: Integrating Lewin's Theory with Lean's System Approach for Change. Online Journal of Issues in Nursing, 21(2), 4. https://doi.org/10.3912/OJIN.Vol21No02Man04, PubMed: $\underline{27854425}$

Wolf, L. A., Perhats, C., Delao, A. M., Clark, P. R., \& Moon, M. D. (2017). On the threshold of safety: A qualitative exploration of nurses' perceptions of factors involved in safe staffing levels in emergency departments. Journal of Emergency Nursing, 43(2), 150157. https://doi.org/10.1016/j.jen.2016.09.003, PubMed: 27836139 
Zodda, D., \& Underwood, J. (2019). Improving emergency department throughput:

Evidence-based strategies aimed at reducing boarding and overcrowding. Physician Leadership Journal, 6(3). https://www.physicianleaders.org/ 


\section{Table 1}

The Budget

\section{EXPENSES}

Total Cost

(Hours)

Direct Training Hour

$\begin{array}{lccc}\text { Nurse Educator } & \$ 55 & 6 & \$ 330 \\ \text { Staff Nurse (ED) } & \$ 40 & 14 & \$ 560 \\ \text { Staff Nurse (Med Surg) } & \$ 40 & 20 & \$ 800 \\ \text { Bed Control Nurse } & \$ 45 & 1 & \$ 45\end{array}$




\section{Figure 1}

ED Timeline for Admitted Patients

\begin{tabular}{|l|l|l|}
\hline Abbreviation or Term & Full Text & Definition \\
\hline ED LOS & $\begin{array}{l}\text { Emergency Department } \\
\text { Length of Stay }\end{array}$ & $\begin{array}{l}\text { Elapsed time, in minutes, between } \\
\text { patient arrival and patient departure }\end{array}$ \\
\hline Patient Arrival & Time of day patient arrives to the ED \\
\hline Admission Order & $\begin{array}{l}\text { Time of day ED provider enters order } \\
\text { to admit patient to hospital }\end{array}$ \\
\hline Patient Departure & $\begin{array}{l}\text { Time of day patient departs the ED } \\
\text { Admission Decision Time } \\
\text { Admission Delay Time } \\
\text { patient arrival and admission order }\end{array}$ \\
\hline * All times are reported in the emergency department integration software (EDIS) system \\
\hline
\end{tabular}

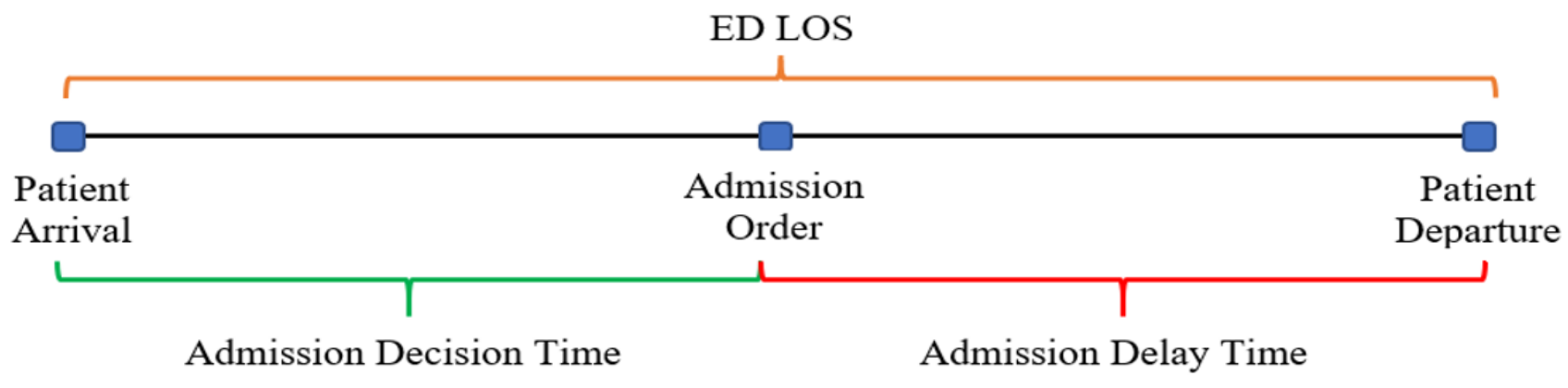


Figure 2

Proposed Future State. Flow Map of Pull Process for Patient Admission

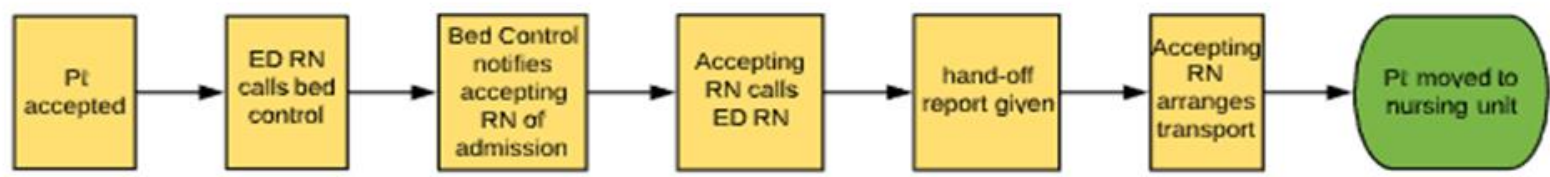


Figure 3

Current State. Flow Map of Current Push Process for Patient Admission.

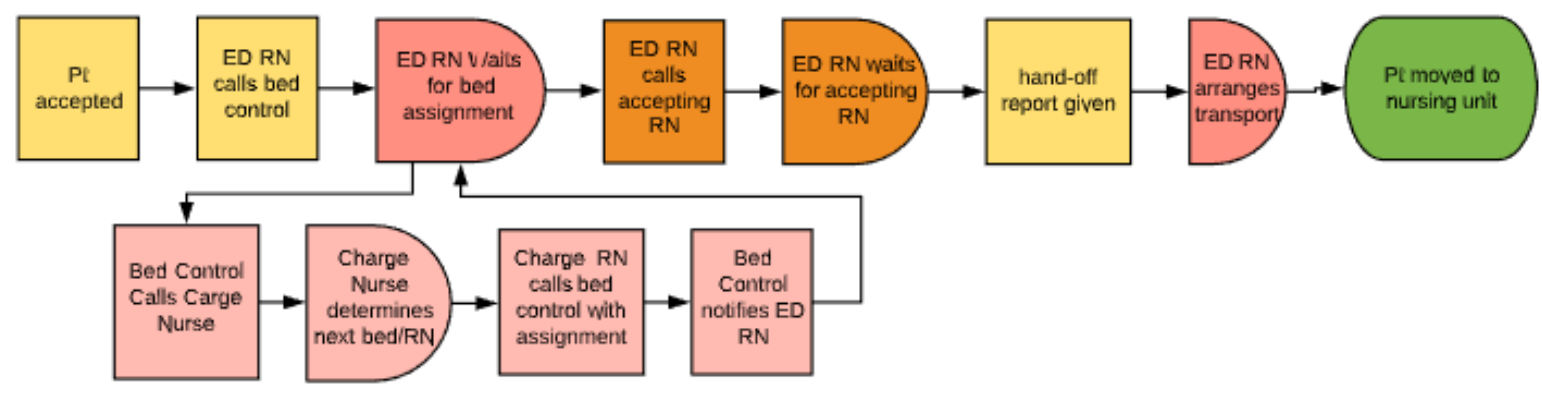




\section{Figure 4}

The Iowa Model-Revised, adapted from the Iowa Model Collaborative. (2017). Copyright 2015 by the University of Iowa Hospitals and Clinics. Used with permission.

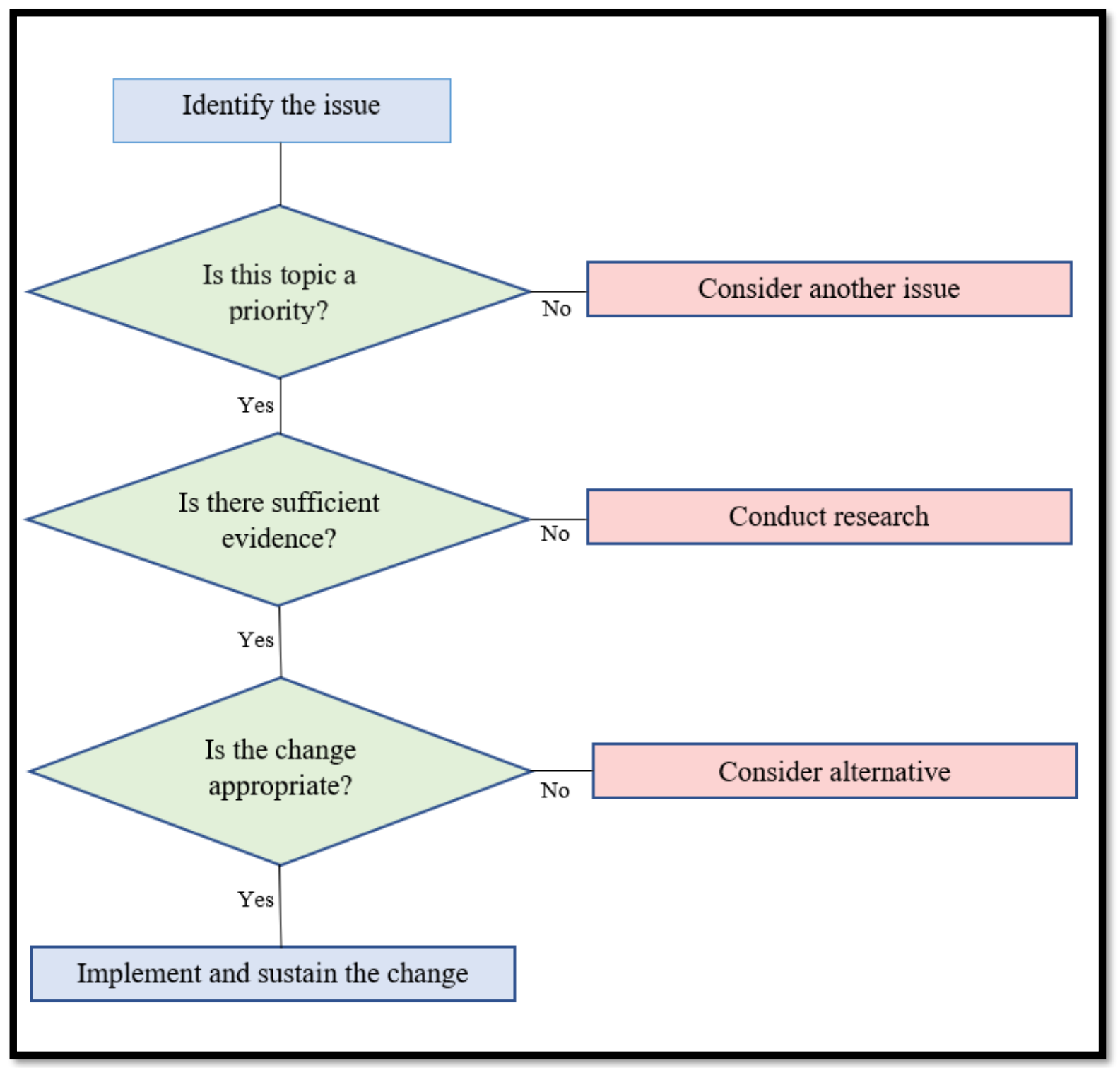




\section{Figure 5}

PRISMA Diagram, adapted from Moher et al. (2010).

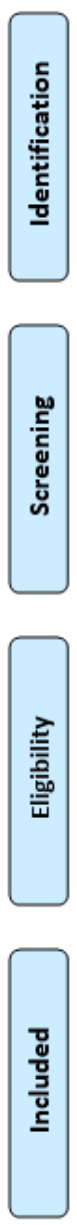

Records identified through database searching ( $n=169)$

Records after duplicates removed

( $n=174)$

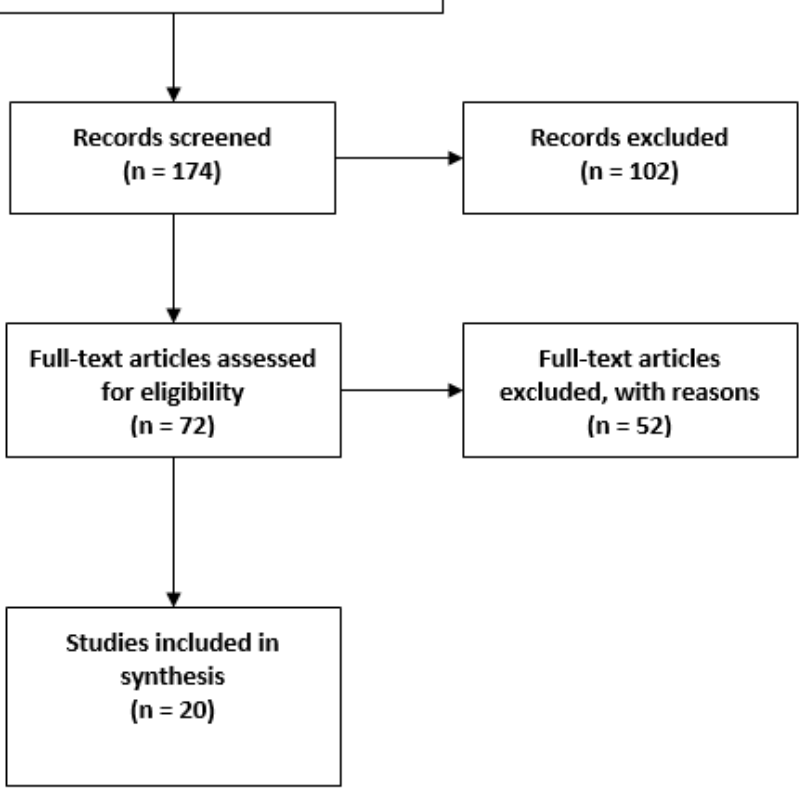




\section{Figure 6.}

Before and After Implementation of Process Change, Unpaired Sample Statistics.

\begin{tabular}{|c|c|c|c|c|c|c|}
\hline Variables & Criteria & Mean & $\mathrm{SD}$ & Df & t-value & $\mathrm{p}$-value \\
\hline \multirow{2}{*}{ Adm Dec } & Before Implementation & 193.11 & 122.47 & \multirow{2}{*}{182} & \multirow{2}{*}{2.370} & \multirow{2}{*}{.019} \\
\hline & After Implementation & 148.84 & 130.82 & & & \\
\hline Adm & Before Implementation & 184.75 & 125.52 & \multirow{2}{*}{182} & \multirow{2}{*}{4.173} & \multirow{2}{*}{$<.001$} \\
\hline Delay & After Implementation & 111.89 & 110.86 & & & \\
\hline \multirow{2}{*}{ LOS } & Before Implementation & 377.86 & 135.85 & \multirow{2}{*}{182} & \multirow{2}{*}{4.663} & \multirow{2}{*}{$<.001$} \\
\hline & After Implementation & 260.73 & 198.98 & & & \\
\hline
\end{tabular}

Note. Significant at the 0.05 level (2-tailed) 


\author{
Appendix A \\ Temporary Operating Procedure
}

October 30, 2020

\title{
Operating Procedure \\ Bed Ahead Process for Medical-Surgical \\ Admissions from the Emergency Department
}

1. PURPOSE: The purpose of this operating procedure is to establish the Bed Ahead process for admissions to the Med/Surg Floor (30-4), originating in the Emergency Department (ED).

2. POLICY: Delays in patient movements have an adverse impact on patient outcomes, contribute to crowding in the ED, and impact the strategic goals of quality, access, and veteran experience. The Healthcare System implements the following process, known as Bed Ahead, for all patients admitted to 30-4 from the ED.

\section{ACTION:}

a. The nursing staff will strive to move the patient to the appropriate theater of care as safely and efficiently as possible.

b. The nursing leadership will assist with implementing this operating procedure.

4. PROCEDURE: This operating procedure established the Bed Ahead Process for admissions to 30-4 originating in the ED. In this process, the next two available beds were identified prior to the request for admission from the ED.

a. The 30-4 Charge Nurse will perform the following:

(1) Assign the next two available beds and admit nurses at the beginning of each shift. 
(2) Within 30 minutes of the start of a shift, call 3-4963 to notify the Bed Flow Coordinator (or PCSC after business hours) of the next two bed and nurse assignments.

(3) Upon accepting an admission, identify the next available bed and nurse, always having the next two available beds and nurses assigned.

(4) Should the need arise to alter the Bed Ahead, immediately notify the Bed Flow Coordinator or PCSC of the new assignment.

(5) Collaborate with the Bed Flow Coordinator or PCSC to ensure safe and efficient patient flow.

(6) Verify that all RNs have an operational and logged-in Vocera device on their person at all times during their shift.

b. The ED Nurse will perform the following:

(1) Verify that an appropriate admission order is placed in the CPRS prior to making a bed request.

(2) Notify the Bed Flow Coordinator or PCSC of the need for admission to 30-

4.

(3) Be available to give a hand-off report once the bed is assigned.

(4) Have an operational and logged-in Vocera device on their person at all times during their shift.

c. The Bed Flow Coordinator or PCSC (after hours) will perform the following:

(1) Ensure that the 30-4 Charge Nurse provides the next two Bed Ahead assignments within 30 minutes of the start of each shift.

(2) Be available by phone to accept admission notifications.

(3) Upon notification of admission, give the next Bed Ahead assignment to the ED. 
(4) Using Vocera, notify the 30-4 nurse (accepting) of the admission.

(5) Have an operational and logged-in Vocera device on their person at all times during their shift.

d. The 30-4 Accepting Nurse will perform the following:

(1) Verify that the Bed Ahead room is available and ready for the patient.

(2) Upon notification of admission, call the ED within 10 minutes to accept the report; if the ED Nurse is unavailable, accept the report from the ED Charge Nurse. In the event that neither is available, call back within 10 minutes.

(3) Be responsible for coordinating the transfer, whether completed by the nurse or delegated to a nursing assistant.

(4) Notify the 30-4 Charge Nurse of patient arrival.

(5) Have an operational and logged-in VORCERA device on their person at all times during their shift.

\section{References}

DiGiacomo, J. C., Angus, L. D. G., Wallace, R., Cardozo-Stolberg, S., Gerber, N., .. . Skarka, K. (2020). The impact of an ICU "bed ahead" policy on ED Length of Stay and Patient Outcomes. Annals of Surgery, 271(2), 303-310. https://doi.org/10.1097/SLA.0000000000002832, PubMed: 29794844

Melton, J. D., Blind, F., Hall, A. B., Leckie, M., \& Novotny, A. (2016). Impact of a hospitalwide quality improvement initiative on emergency department throughput and crowding measures. Joint Commission Journal on Quality and Patient Safety, 42(12), 533-542. https://doi.org/10.1016/S1553-7250(16)30104-0, PubMed: 28334556 Appropriate VHA policy and Station Memorandum for Hand-Off Report, SBAR, Vocera Usage, and Admission Policy. 
6. EFFECTIVE DATES: This temporary policy shall be in effect during the implementation of the Improving Emergency Department Throughput: Using a Pull Method of Patient Flow project being conducted by Jeffrey Collins, MSN, RN. Upon completion of the project, this policy may be adopted as a Nursing Standard Operating Procedure. Unless superseded, this temporary policy will expire upon termination of the project, or on May 31, 2021, whichever occurs first.

M. Christopher Saslo, DNS, ARNP-BC, FAANP

Associate Director for Patient Care Services/Nurse Executive 
Appendix B

Summary of Primary Research Evidence

\begin{tabular}{|c|c|c|c|c|c|c|}
\hline Citation & $\begin{array}{c}\text { Design level } \\
\text { Quality Grade }\end{array}$ & $\begin{array}{c}\text { Sample } \\
\text { Sample Size }\end{array}$ & \begin{tabular}{|l}
\multicolumn{1}{|c}{ Intervention } \\
\multicolumn{1}{|c}{ Comparison } \\
(Definitions \\
should include \\
any specific \\
research tools \\
used along with \\
reliability and \\
validity)
\end{tabular} & $\begin{array}{l}\text { Theoretical } \\
\text { Foundation }\end{array}$ & $\begin{array}{c}\text { Outcome } \\
\text { Definition }\end{array}$ & \begin{tabular}{|c|} 
Usefulness \\
Results \\
Key Findings
\end{tabular} \\
\hline $\begin{array}{l}\text { Artenstein, A. W., Rathlev, N. K., Neal, D., } \\
\text { Townsend, V., Vemula, M., Goldlust, S.,...Tuomi, } \\
\text { M. (2017). Decreasing emergency department } \\
\text { walkout rate and boarding hours by improving } \\
\text { inpatient length of stay. Western Journal of } \\
\text { Emergency Medicine, 18(6), 982-992. } \\
\text { https://doi.org/10.5811/westjem.2017.7.34663, } \\
\text { PubMed: } \underline{29085527}\end{array}$ & $\begin{array}{l}\text { Quality } \\
\text { improvement } \\
\text { initiative using } \\
\text { a pre/post } \\
\text { analysis } \\
\text { Level II } \\
\text { Grade A }\end{array}$ & $\begin{array}{l}\text { Five site, } \\
\text { single } \\
\text { system, } 24 \\
\text { months }\end{array}$ & $\begin{array}{l}\text { Three teams } \\
\text { focused on ED } \\
\text { efficiency, bed } \\
\text { management and } \\
\text { interdisciplinary } \\
\text { plan of care } \\
\text { teams }\end{array}$ & $\begin{array}{l}\text { Lean-Six } \\
\text { Sigma }\end{array}$ & $\begin{array}{l}\text { Admission } \\
\text { delay, inpatient } \\
\text { LOS, LWBS }\end{array}$ & $\begin{array}{l}\text { LWBS rates } \\
\text { decreased and } \\
\text { admission } \\
\text { delay } \\
\text { remained } \\
\text { stable with } \\
\text { increased } \\
\text { volume. }\end{array}$ \\
\hline $\begin{array}{l}\text { Chartier, L. B., Simoes, L., Kuipers, M., \& } \\
\text { McGovern, B. (2016). Improving emergency } \\
\text { department flow through optimized bed } \\
\text { utilization. BMJ Quality Improvement } \\
\text { Reports, 5(1). } \\
\text { https://doi.org/10.1136/bmjquality.u206156.w2532, } \\
\text { PubMed: } \underline{27752312}\end{array}$ & $\begin{array}{l}\text { Quasi- } \\
\text { experimental, } \\
\text { quality } \\
\text { improvement } \\
\text { Level II, Grade } \\
\text { B }\end{array}$ & $\begin{array}{l}2,354 \text { patient } \\
\text { visits }\end{array}$ & $\begin{array}{l}\text { PDSA cycles. } \\
\text { Used established } \\
\text { EDIS measures } \\
\text { to track time to } \\
\text { bed for high } \\
\text { acuity patients }\end{array}$ & $\begin{array}{l}\text { Highly } \\
\text { Adoptable } \\
\text { Improvement } \\
\text { (HAI) model }\end{array}$ & $\begin{array}{l}\text { Study found } \\
\text { that low-tech } \\
\text { communication } \\
\text { systems } \\
\text { showed } \\
\text { greatest gains. }\end{array}$ & $\begin{array}{l}\text { High-tech } \\
\text { solutions } \\
\text { resulted in } \\
\text { limited } \\
\text { utilization and } \\
\text { buy-in from } \\
\text { frontline staff. }\end{array}$ \\
\hline $\begin{array}{l}\text { Claret, P. G., Boudemaghe, T., Bobbia, X., } \\
\text { Stowell, A., Miard, É., Sebbane, M.,...De La } \\
\text { Coussaye, J. E. (2016). Consequences for }\end{array}$ & $\begin{array}{l}\text { Quasi- } \\
\text { experimental, } \\
\text { observational, }\end{array}$ & $\begin{array}{l}2347 \\
\text { patients }\end{array}$ & $\begin{array}{l}\text { Used computer } \\
\text { simulation to } \\
\text { predict the }\end{array}$ & Not disclosed & $\begin{array}{l}\text { Planned } \\
\text { admission had } \\
\text { a lower LOS }\end{array}$ & $\begin{array}{l}\text { Postponing } \\
\text { scheduled } \\
\text { surgeries does }\end{array}$ \\
\hline
\end{tabular}




\begin{tabular}{|c|c|c|c|c|c|c|}
\hline $\begin{array}{l}\text { overcrowding in the emergency room of a change } \\
\text { in bed management policy on available in-hospital } \\
\text { beds. Australian Health Review, } 40(4), 466-472 . \\
\text { https://doi.org/10.1071/AH15088, PubMed: } \\
26476497\end{array}$ & $\begin{array}{l}\text { and descriptive } \\
\text { study computer } \\
\text { simulation } \\
\text { Level II, } \\
\text { Grade B }\end{array}$ & & $\begin{array}{l}\text { impact of } \\
\text { prioritizing ED } \\
\text { admissions over } \\
\text { planned surgical } \\
\text { admissions. }\end{array}$ & & $\begin{array}{l}\text { and in-hospital } \\
\text { mortality }\end{array}$ & $\begin{array}{l}\text { not reduce ED } \\
\text { crowding or } \\
\text { improve LOS. }\end{array}$ \\
\hline $\begin{array}{l}\text { DeAnda (2018). Stop the bottleneck: Improving } \\
\text { patient throughput in the emergency } \\
\text { department. Journal of Emergency Nursing, 44(6), } \\
\text { 582-588. https://doi.org/10.1016/j.jen.2018.05.002, } \\
\text { PubMed: } 29935944\end{array}$ & $\begin{array}{l}\text { Quasi- } \\
\text { experimental, } \\
\text { quality } \\
\text { improvement } \\
\text { Level II, } \\
\text { Grade C }\end{array}$ & $\begin{array}{l}\text { Single site } \\
\text { QI project }\end{array}$ & $\begin{array}{l}\text { Used a patient } \\
\text { flow nurse to } \\
\text { coordinate } \\
\text { patient } \\
\text { movements for } \\
\text { admitted } \\
\text { patients. EDIS } \\
\text { measures were } \\
\text { used to monitor } \\
\text { outcomes. } \\
\end{array}$ & $\begin{array}{l}\text { Model for } \\
\text { improvement }\end{array}$ & $\begin{array}{l}\text { Process time of } \\
\text { moving } \\
\text { patients from } \\
\text { the ED to the } \\
\text { inpatient ward }\end{array}$ & $\begin{array}{l}\text { Use of a flow } \\
\text { nurse resulted } \\
\text { in improved } \\
\text { process times. }\end{array}$ \\
\hline $\begin{array}{l}\text { DiGiacomo, J. C., Angus, L. D. G., Wallace, R., } \\
\text { Cardozo-Stolberg, S., Gerber, N., Munnangi, } \\
\text { S.,...Skarka, K. (2020). The impact of an ICU “bed } \\
\text { ahead” policy on ED length of stay and patient } \\
\text { outcomes. Annals of Surgery, 271(2), 303-310. } \\
\text { https://doi.org/10.1097/SLA.0000000000002832, } \\
\text { PubMed: } 29794844\end{array}$ & $\begin{array}{l}\text { Retrospective } \\
\text { observational } \\
\text { study, pre- and } \\
\text { post- analysis } \\
\text { Level II } \\
\text { Grade A }\end{array}$ & $\begin{array}{l}657 \text { per } 653 \\
\text { posts }\end{array}$ & $\begin{array}{l}\text { Implemented a } \\
\text { bed-ahead } \\
\text { protocol for } \\
\text { surgical ICU }\end{array}$ & Not disclosed & $\begin{array}{l}\text { ED LOS, ICU } \\
\text { LOS, hospital } \\
\text { LOS, in- } \\
\text { hospital } \\
\text { mortality }\end{array}$ & $\begin{array}{l}\text { Bed ahead } \\
\text { protocol } \\
\text { resulted in } \\
\text { reductions in } \\
\text { the ED LOS, } \\
\text { ICU LOS, } \\
\text { hospital LOS, } \\
\text { in-hospital } \\
\text { mortality. }\end{array}$ \\
\hline $\begin{array}{l}\text { Hitti, E. A., El-Eid, G. R., Tamim, H., Saleh, R., } \\
\text { Saliba, M., \& Naffaa, L. (2017). Improving } \\
\text { emergency department radiology transportation } \\
\text { time: A successful implementation of lean } \\
\text { methodology. BMC Health Services } \\
\text { Research, } 17(1) \text {, } \\
\text { 625.https://doi.org/10.1186/s12913-017-2488-5, } \\
\text { PubMed: } 28870249\end{array}$ & $\begin{array}{l}\text { Quasi- } \\
\text { experimental, } \\
\text { quality } \\
\text { improvement } \\
\text { Level II, } \\
\text { Grade A }\end{array}$ & $\begin{array}{l}6186 \text { pre- } \\
\text { interventions } \\
4879 \text { post- } \\
\text { interventions }\end{array}$ & $\begin{array}{l}\text { Descriptive } \\
\text { statistics. Used } \\
\text { the pull system } \\
\text { to improve } \\
\text { radiographic } \\
\text { study turnaround } \\
\text { time. }\end{array}$ & $\begin{array}{l}\text { Value Stream } \\
\text { Mapping } \\
\text { (VSM) }\end{array}$ & $\begin{array}{l}\text { Turnaround } \\
\text { times were } \\
\text { reduced by } \\
57 \% \text { by using } \\
\text { pull method. } \\
\text { Overall, the ED } \\
\text { LOS was also } \\
\text { reduced by } \\
24 \% \text {. }\end{array}$ & $\begin{array}{l}\text { The study } \\
\text { demonstrated } \\
\text { that the pull } \\
\text { method can } \\
\text { improve ED } \\
\text { time metrics, } \\
\text { without } \\
\text { additional } \\
\text { manpower. }\end{array}$ \\
\hline
\end{tabular}




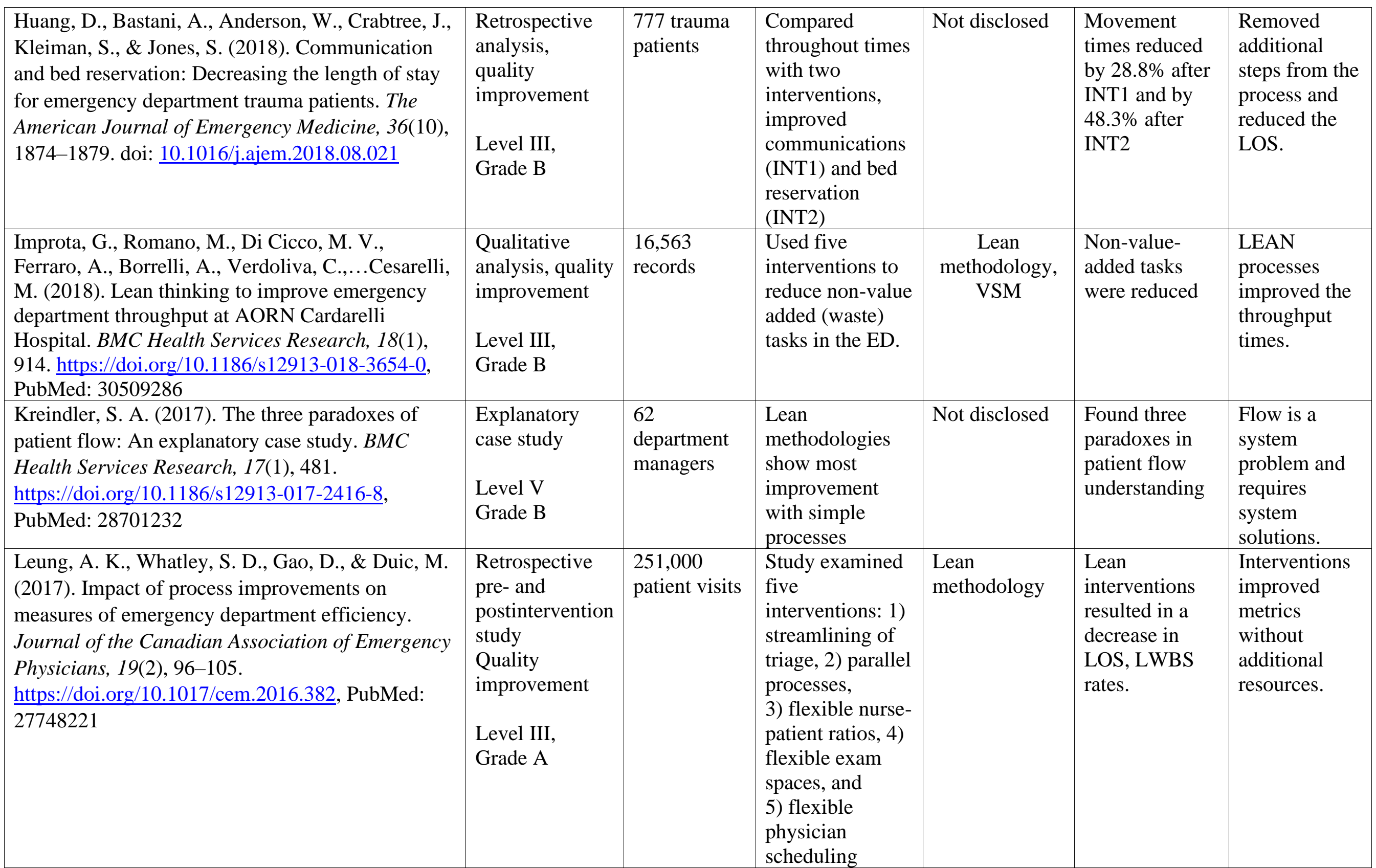




\begin{tabular}{|c|c|c|c|c|c|c|}
\hline $\begin{array}{l}\text { Liu, A., Kline, D. M., Brock, G. N., \& Bonsu, B. } \\
\text { K. (2019). Multistate model of the patient flow } \\
\text { process in the pediatric emergency } \\
\text { department. PLOS ONE, 14(7), e0219514. } \\
\text { https://doi.org/10.1371/journal.pone.0219514, } \\
\text { PubMed: } 31291345\end{array}$ & $\begin{array}{l}\text { Retrospective } \\
\text { analysis } \\
\text { Level V } \\
\text { Grade B }\end{array}$ & $\begin{array}{l}75,591 \\
\text { patient visits }\end{array}$ & $\begin{array}{l}\text { Modeled five } \\
\text { transition times, } \\
\text { compared to the } \\
\text { ESI level }\end{array}$ & $\begin{array}{l}\text { Statistical } \\
\text { analysis }\end{array}$ & $\begin{array}{l}\text { ED delays } \\
\text { impact } \\
\text { overcrowding, } \\
\text { LOS, and } \\
\text { mortality. }\end{array}$ & $\begin{array}{l}\text { Delay in } \\
\text { movements } \\
\text { out of ED } \\
\text { negatively } \\
\text { impacts } \\
\text { overcrowding }\end{array}$ \\
\hline $\begin{array}{l}\text { Mathews, K. S., \& Long, E. F. (2015). A } \\
\text { conceptual framework for improving critical care } \\
\text { patient flow and bed use. Annals of the American } \\
\text { Thoracic Society, 12(6), 886-894,E1-E14. } \\
\text { https://doi.org/10.1513/AnnalsATS.201409- } \\
\text { 419OC, PubMed: } 25822477\end{array}$ & $\begin{array}{l}\text { Retrospective } \\
\text { analysis } \\
\text { Level V } \\
\text { Grade B }\end{array}$ & $\begin{array}{l}2,710 \text { adult } \\
\text { patients }\end{array}$ & $\begin{array}{l}\text { Presented a } \\
\text { model for } \\
\text { prioritizing ICU } \\
\text { patient } \\
\text { placement }\end{array}$ & $\begin{array}{l}\text { Queuing } \\
\text { theory }\end{array}$ & $\begin{array}{l}\text { ED patients } \\
\text { were given } \\
\text { priority } \\
\text { placement over }\end{array}$ & $\begin{array}{l}\text { Prioritized } \\
\text { placement of } \\
\text { ED patients } \\
\text { reduced ED } \\
\text { LOS. }\end{array}$ \\
\hline $\begin{array}{l}\text { McCaughey, D., Erwin, C. O., \& DelliFraine, J. L. } \\
\text { (2015). Improving capacity management in the } \\
\text { emergency department: A review of the literature, } \\
\text { 2000-2012. Journal of Healthcare } \\
\text { Management/American College of Healthcare } \\
\text { Executives, 60(1), 63-75. } \\
\text { https://journals.lww.com/jhmonline. } \\
\text { https://doi.org/10.1097/00115514-201501000- } \\
\text { 00011, PubMed: } 26529995\end{array}$ & $\begin{array}{l}\text { Literature } \\
\text { review } \\
\text { Level V } \\
\text { Grade A }\end{array}$ & $\begin{array}{l}1,780 \\
\text { articles } \\
\text { reviewed } \\
23 \text { articles } \\
\text { included }\end{array}$ & $\begin{array}{l}\text { Literature review } \\
\text { examined } \\
\text { available } \\
\text { literature on ED } \\
\text { capacity } \\
\text { management, } \\
\text { and the literature } \\
\text { was classified } \\
\text { into four themes: } \\
\text { problems, } \\
\text { solutions, } \\
\text { outcomes, and } \\
\text { metrics. }\end{array}$ & $\begin{array}{l}\text { Literature } \\
\text { review }\end{array}$ & $\begin{array}{l}\text { Patient flow is } \\
\text { a system-wide } \\
\text { issue and needs } \\
\text { system-wide } \\
\text { solutions. }\end{array}$ & $\begin{array}{l}\text { Lack of } \\
\text { industry-wide } \\
\text { metrics, tools, } \\
\text { and } \\
\text { definitions } \\
\text { limits } \\
\text { research. }\end{array}$ \\
\hline $\begin{array}{l}\text { McCoy, J. V., Gale, A. R., Sunderram, J., Ohman- } \\
\text { Strickland, P. A., \& Eisenstein, R. M. (2015). } \\
\text { Reduced hospital duration of stay associated with } \\
\text { revised emergency department-intensive care unit } \\
\text { admission policy: A before and after study. Journal } \\
\text { of Emergency Medicine, 49(6), 893-900. }\end{array}$ & $\begin{array}{l}\text { Retrospective } \\
\text { Observational } \\
\text { Study, pre and } \\
\text { post analysis } \\
\text { Level II } \\
\text { Grade A }\end{array}$ & $\begin{array}{l}225 \text { pre, } 273 \\
\text { post }\end{array}$ & $\begin{array}{l}\text { Removed } \\
\text { unnecessary } \\
\text { screening from } \\
\text { the admission } \\
\text { process }\end{array}$ & Not disclosed & $\begin{array}{l}\text { ED LOS, ICU } \\
\text { LOS, days on } \\
\text { ventilator, } \\
\text { mortality }\end{array}$ & $\begin{array}{l}\text { Delays in ED } \\
\text { stay were } \\
\text { amplified in } \\
\text { ICU LOS }\end{array}$ \\
\hline
\end{tabular}




\begin{tabular}{|c|c|c|c|c|c|c|}
\hline $\begin{array}{l}\text { https://doi.org/10.1016/j.jemermed.2015.06.067, } \\
\text { PubMed: } 26409680\end{array}$ & & & & & & \\
\hline $\begin{array}{l}\text { Melton, J. D., Blind, F., Hall, A. B., Leckie, M., \& } \\
\text { Novotny, A. (2016). Impact of a hospitalwide } \\
\text { quality improvement initiative on emergency } \\
\text { department throughput and crowding } \\
\text { measures. Joint Commission Journal on Quality } \\
\text { and Patient Safety, 42(12), 533-542. } \\
\text { https://doi.org/10.1016/S1553-7250(16)30104-0, } \\
\text { PubMed: } \underline{28334556}\end{array}$ & $\begin{array}{l}\text { Retrospective } \\
\text { observational } \\
\text { study, pre and } \\
\text { post analysis } \\
\text { Level II } \\
\text { Grade A }\end{array}$ & $\begin{array}{l}666,640 \\
\text { patient visits }\end{array}$ & $\begin{array}{l}\text { Used bed ahead } \\
\text { protocol to } \\
\text { reduce } \\
\text { admission delays } \\
\text { and multiple } \\
\text { other } \\
\text { interventions } \\
\text { related to ED } \\
\text { throughput }\end{array}$ & Lean & $\begin{array}{l}\text { Admission } \\
\text { delay }\end{array}$ & $\begin{array}{l}\text { Bed ahead } \\
\text { protocol } \\
\text { reduced } \\
\text { admission } \\
\text { delays from } \\
\text { the ED. }\end{array}$ \\
\hline $\begin{array}{l}\text { Vashi, A.A., Lerner, B., Urech, T. H., Asch, S. M., } \\
\text { \& Charns, M. P. (2019). Lean enterprise } \\
\text { transformation in VA: A national evaluation } \\
\text { framework and study protocol. BMC Health } \\
\text { Services Research, 19(1), 98. } \\
\text { https://doi.org/10.1186/s12913-019-3919-2, } \\
\text { PubMed: 30717729 }\end{array}$ & $\begin{array}{l}\text { Literature } \\
\text { review, } \\
\text { Framework } \\
\text { Development } \\
\text { Level V, } \\
\text { Grade B }\end{array}$ & $\begin{array}{l}170 \text { sites } \\
\text { with } 10 \text { site } \\
\text { pilots }\end{array}$ & $\begin{array}{l}\text { Established a } \\
\text { framework for } \\
\text { Lean thinking } \\
\text { transformation } \\
\text { using a mixed- } \\
\text { method study }\end{array}$ & $\begin{array}{l}\text { Organizational } \\
\text { Transformation } \\
\text { Model }\end{array}$ & $\begin{array}{l}\text { Implementation } \\
\text { framework }\end{array}$ & $\begin{array}{l}\text { Ten domains } \\
\text { and } 24 \\
\text { constructs }\end{array}$ \\
\hline $\begin{array}{l}\text { Willard, E., Carlton, E. F., Moffat, L., \& Barth, B. } \\
\text { E. (2017). A full-capacity protocol allows for } \\
\text { increased emergency patient volume and hospital } \\
\text { admissions. Journal of Emergency Nursing, 43(5), } \\
\text { 413-418. https://doi.org/10.1016/j.jen.2017.01.007, } \\
\text { PubMed: 28456336 }\end{array}$ & $\begin{array}{l}\text { Quality } \\
\text { improvement } \\
\text { initiative using } \\
\text { a pre/post } \\
\text { analysis } \\
\text { Level III } \\
\text { Grade C }\end{array}$ & Single site & $\begin{array}{l}\text { Implemented a } \\
\text { full capacity } \\
\text { protocol on days } \\
\text { when ED } \\
\text { overcrowding } \\
\text { was present. } \\
\text { Used leadership } \\
\text { huddles to } \\
\text { reduce barriers } \\
\text { to patient flow. }\end{array}$ & Not disclosed & $\begin{array}{l}\text { LOS, LWBS, } \\
\text { admission rate }\end{array}$ & $\begin{array}{l}\text { LOS } \\
\text { increased on } \\
\text { days of full } \\
\text { capacity. }\end{array}$ \\
\hline
\end{tabular}

Note. ED - emergency department, ICU - intensive care unit, LOS - length of stay, LWBS - left without being seen, RPIW - rapid process improvement

workshop, PDSA - plan do study act, EDIS - emergency department information system, ESI - Emergency Severity Index 
Appendix C

Summary of Systematic Reviews (SR)

\begin{tabular}{|c|c|c|c|c|c|c|c|}
\hline Citation & \begin{tabular}{|l|} 
Qualit \\
y \\
Grade
\end{tabular} & Question & $\begin{array}{l}\text { Search } \\
\text { Strategy }\end{array}$ & $\begin{array}{l}\text { Inclusion/Exclusio } \\
\text { n Criteria }\end{array}$ & $\begin{array}{l}\text { Data } \\
\text { Extraction } \\
\text { and } \\
\text { Analysis } \\
\end{array}$ & \begin{tabular}{|l|} 
Key \\
Findings
\end{tabular} & $\begin{array}{l}\text { Usefulness/Recommendations/Implicati } \\
\text { ons }\end{array}$ \\
\hline $\begin{array}{l}\text { Mousavi Isfahani, H., Tourani, S., } \\
\text { \& Seyedin, H. (2019). Lean } \\
\text { management approach in hospitals: } \\
\text { A systematic review. International } \\
\text { Journal of Lean Six Sigma, 10(1), } \\
\text { 161-188. } \\
\text { https://doi.org/10.1108/IJLSS-05- } \\
\text { 2017-0051 }\end{array}$ & \begin{tabular}{|l} 
Level \\
II \\
Grade \\
A
\end{tabular} & \begin{tabular}{|l} 
Lean \\
management \\
approach in \\
hospitals
\end{tabular} & $\begin{array}{l}\text { PubMed, } \\
\text { Web } \\
\text { of } \\
\text { Knowledge, } \\
\text { Google } \\
\text { Scholar, } \\
\text { Scopus, } \\
\text { Iranmedex, } \\
\text { SID, } \\
\text { Magiran } \\
\text { and Medlib } \\
\end{array}$ & $\begin{array}{l}\text { English and } \\
\text { Persian languages, } \\
\text { January } 2000 \text { to } \\
\text { August } 2015 \\
\text { Excluded: those } \\
\text { that did not have } \\
\text { the full text, } \\
\text { presentations, } \\
\text { narrative reviews, } \\
\text { qualitative studies, } \\
\text { educational studies }\end{array}$ & $\begin{array}{l}\text { STROBE } \\
\text { Manual } \\
\text { review } \\
\text { extraction } \\
\text { table }\end{array}$ & \begin{tabular}{|l|} 
Lean \\
resulted in \\
improvement \\
s \\
Lean \\
thinking can \\
lead to \\
quality \\
improvement \\
s
\end{tabular} & $\begin{array}{l}\text { Shows the applicability of Lean for } \\
\text { hospital improvement }\end{array}$ \\
\hline $\begin{array}{l}\text { Raja Sreedharan, V., \& Raju, R. } \\
\text { (2016). A systematic literature } \\
\text { review of lean Six Sigma in } \\
\text { different industries. International } \\
\text { Journal of Lean Six Sigma, 7(4), } \\
\text { 430-466. } \\
\text { https://doi.org/10.1108/IJLSS-12- } \\
2015-0050\end{array}$ & $\begin{array}{l}\text { Level } \\
\text { II } \\
\text { Grade } \\
\text { B }\end{array}$ & \begin{tabular}{|l|} 
Report \\
different \\
definitions, \\
demographic \\
s, \\
methodologie \\
s and \\
industries
\end{tabular} & $\begin{array}{l}\text { Emerald, } \\
\text { Taylor and } \\
\text { Francis, } \\
\text { IEEE, } \\
\text { Inderscienc } \\
\text { e, Elsevier } \\
\text { and Google } \\
\text { Scholar }\end{array}$ & $\begin{array}{l}\text { January } 2003 \text { to } \\
\text { May } 2015 \\
\text { "Lean Sigma" and } \\
\text { "Lean Six Sigma/ } \\
\text { book } \\
\text { reviews, prefaces, } \\
\text { and editorial notes } \\
\text { were excluded }\end{array}$ & $\begin{array}{l}\text { Research } \\
\text { methodolog } \\
\text { y, type of } \\
\text { industry, } \\
\text { author } \\
\text { profile, } \\
\text { country of } \\
\text { Research, } \\
\text { and year of } \\
\text { publication }\end{array}$ & \begin{tabular}{|l|} 
Despite \\
variations in \\
terminology, \\
the use of \\
Lean and Six \\
Sigma has \\
increased \\
across \\
industries
\end{tabular} & $\begin{array}{l}\text { Lean thinking has been successful in } \\
\text { multiple industries }\end{array}$ \\
\hline $\begin{array}{l}\text { Rasouli, H. R., Esfahani, A. A., } \\
\text { Nobakht, M., Eskandari, M., } \\
\text { Mahmoodi, S., Goodarzi, H., \& } \\
\text { Abbasi Farajzadeh, M. (2019). } \\
\text { Outcomes of crowding in } \\
\text { emergency departments; a }\end{array}$ & $\begin{array}{l}\text { Level } \\
\text { II } \\
\text { Grade } \\
\text { A }\end{array}$ & $\begin{array}{l}\text { challenges } \\
\text { and } \\
\text { outcomes } \\
\text { of ED } \\
\text { crowding }\end{array}$ & $\begin{array}{l}\text { PubMed } \\
\text { (MEDLINE } \\
\text { and } \\
\text { Embase }\end{array}$ & \begin{tabular}{|l} 
English \\
January 1, 2007 to \\
January 1,2019 \\
effects \\
and consequences \\
of ED crowding/ \\
\end{tabular} & $\begin{array}{l}\text { Critical } \\
\text { Appraisal } \\
\text { Skills } \\
\text { Programme } \\
\text { (CASP) }\end{array}$ & $\begin{array}{l}\text { Crowding } \\
\text { negatively } \\
\text { affects the } \\
\text { quality of } \\
\text { emergency } \\
\text { healthcare }\end{array}$ & $\begin{array}{l}\text { ED crowding negatively impacts } \\
\text { efficiency, quality, and process }\end{array}$ \\
\hline
\end{tabular}




\begin{tabular}{|c|c|c|c|c|c|c|c|}
\hline $\begin{array}{l}\text { systematic review. Archives of } \\
\text { Academic Emergency } \\
\text { Medicine, 7(1), e52. } \\
\text { http://journals.sbmu.ac.ir/aaem. } \\
\text { PubMed: } 31602435 \\
\end{array}$ & & & & $\begin{array}{l}\text { case reports, } \\
\text { systematic reviews } \\
\text { excluded }\end{array}$ & \begin{tabular}{|l} 
Joanna \\
Briggs \\
Institute \\
Meta- \\
Analysis of \\
Statistics \\
Assessment \\
and Review \\
Instrument \\
(JBI- \\
MAStARI) \\
PRISMA \\
\end{tabular} & & \\
\hline $\begin{array}{l}\text { Walker, C., Kappus, K., \& Hall, N. } \\
\text { (2016). Strategies for improving } \\
\text { patient throughput in an acute care } \\
\text { setting resulting in improved } \\
\text { outcomes: A systematic } \\
\text { review. Nursing Economics, 34(6), } \\
\text { 277-288. } \\
\text { http://www.nursingeconomics.net/c } \\
\text { gi- } \\
\text { bin/WebObjects/NECJournal.woa. } \\
\text { PubMed: } 29975490\end{array}$ & $\begin{array}{l}\text { Level } \\
\text { II } \\
\text { Grade } \\
\text { B }\end{array}$ & $\begin{array}{l}\text { Strategies for } \\
\text { improving } \\
\text { patient } \\
\text { throughput }\end{array}$ & $\begin{array}{l}\text { Academic } \\
\text { Search, } \\
\text { Business } \\
\text { Insight, } \\
\text { Business } \\
\text { Source } \\
\text { Premier, } \\
\text { CINAHL } \\
\text { Plus } \\
\text { with Full } \\
\text { Text, } \\
\text { Cochran } \\
\text { Library, } \\
\text { COM } \\
\text { Abstract, } \\
\text { Corporate } \\
\text { Resource } \\
\text { Net, CQ } \\
\text { Researcher, } \\
\text { Health } \\
\text { Business } \\
\text { Full Text, } \\
\text { JBI }\end{array}$ & \begin{tabular}{|l|} 
Peer-reviewed \\
English \\
2008-2014 \\
practices to \\
improve patient \\
throughput/ \\
Excluded those \\
with unit-specific, \\
outside the hospital \\
settings
\end{tabular} & $\begin{array}{l}\text { Melnyk's } \\
\text { Criteria for } \\
\text { Literature } \\
\text { Review }\end{array}$ & $\begin{array}{l}\text { Efficiency is } \\
\text { impacted } \\
\text { from the } \\
\text { point of } \\
\text { entry } \\
\text { through } \\
\text { discharge. }\end{array}$ & Patient flow is a system wide issue. \\
\hline
\end{tabular}




\begin{tabular}{|l|l|l|l|l|l|}
\hline & & & & & \\
\hline & $\begin{array}{l}\text { Connect, } \\
\text { Medline } \\
\text { Plus, Ovid, } \\
\text { and } \\
\text { Regional } \\
\text { Business }\end{array}$ & & & \\
\hline
\end{tabular}

Note. ED - emergency department 
Appendix D

SWOT Analysis

\begin{tabular}{|c|c|}
\hline Factor & Explanation \\
\hline \multicolumn{2}{|l|}{ Strength } \\
\hline Stakeholder support & Stakeholders understand the need for the project. \\
\hline Facility is active in EBP & Employees are already familiar with the EBP process. \\
\hline Minimal costs to the facility & $\begin{array}{l}\text { Facility costs was limited to the training and coordination time } \\
\text { for the project. }\end{array}$ \\
\hline \multicolumn{2}{|r|}{ ( } \\
\hline Staff participation & $\begin{array}{l}\text { Some staff members may be reluctant to participate in a new } \\
\text { process. }\end{array}$ \\
\hline Staff working multiple EBPs & $\begin{array}{l}\text { There exists a possibility of staff burnout due to the number of } \\
\text { ongoing projects. }\end{array}$ \\
\hline Change in culture & $\begin{array}{l}\text { Some employees tend to become ingrained in the current } \\
\text { processes and ways of performing tasks. }\end{array}$ \\
\hline \multicolumn{2}{|l|}{ Opportunities } \\
\hline Improve patient outcomes & Decreasing delays improves patient care. \\
\hline Improve patient satisfaction & Patient are dissatisfied will delays in care. \\
\hline Improve quality metrics & The facility is failing to meet ED quality benchmarks. \\
\hline \multicolumn{2}{|l|}{ Threats } \\
\hline Labor partner objections & $\begin{array}{l}\text { The labor union can object to changes in the process if they feel } \\
\text { it creates a burden on employees. }\end{array}$ \\
\hline Bureaucratic delays & Process approvals tend to take longer at this facility. \\
\hline Short timeline & Creates need to agile changes during project. \\
\hline
\end{tabular}


Appendix E

Risk Assessment

\begin{tabular}{lcccc}
\hline \multicolumn{1}{c}{ Risk } & Impact & Probability & Score & Action \\
\hline $\begin{array}{l}\text { Increased wait time } \\
\text { due to project }\end{array}$ & 4 & 1 & 4 & Mitigate \\
$\begin{array}{l}\text { implementation } \\
\begin{array}{l}\text { Decrease patient } \\
\text { satisfaction }\end{array}\end{array}$ & 5 & 1 & 5 & Eliminate \\
$\begin{array}{l}\text { Decreased staff } \\
\text { satisfaction }\end{array}$ & 4 & 3 & 12 & Mitigate \\
$\begin{array}{l}\text { Decrease in quality } \\
\text { of care }\end{array}$ & 5 & 1 & 5 & Mitigate \\
\hline
\end{tabular}

Note. The scale is from 1 to 5, with, with 1 being no impact/probability, score product of impact, and probability scores 
Appendix F

Project Schedule

\begin{tabular}{|c|c|c|c|c|c|c|c|c|c|c|c|c|c|c|c|c|c|c|c|c|c|c|c|c|}
\hline & $\mathrm{NU}$ & 801 & & & & & & & & 802 & & & & & & & $\mathrm{NU}$ & 803 & & & & & & \\
\hline Activity & $\begin{array}{l}\mathrm{W} \\
\mathrm{e} \\
\mathrm{e} \\
\mathrm{k} \\
1\end{array}$ & $\begin{array}{l}\text { W } \\
\mathrm{e} \\
\mathrm{e} \\
\mathrm{k} \\
3\end{array}$ & $\begin{array}{l}\text { W } \\
\text { e } \\
\text { e } \\
\mathrm{k} \\
5\end{array}$ & $\begin{array}{l}\text { W } \\
\mathrm{e} \\
\mathrm{e} \\
\mathrm{k} \\
7\end{array}$ & $\begin{array}{l}\text { W } \\
\mathrm{e} \\
\mathrm{e} \\
\mathrm{k} \\
9\end{array}$ & $\begin{array}{l}\mathrm{W} \\
\mathrm{e} \\
\mathrm{e} \\
\mathrm{k} \\
1 \\
1\end{array}$ & $\begin{array}{l}\mathrm{W} \\
\mathrm{e} \\
\mathrm{e} \\
\mathrm{k} \\
1 \\
3 \\
\end{array}$ & $\begin{array}{l}\mathrm{W} \\
\mathrm{e} \\
\mathrm{e} \\
\mathrm{k} \\
1 \\
5 \\
\end{array}$ & $\begin{array}{l}\mathrm{W} \\
\mathrm{e} \\
\mathrm{e} \\
\mathrm{k} \\
1\end{array}$ & $\begin{array}{l}\mathrm{W} \\
\mathrm{e} \\
\mathrm{e} \\
\mathrm{k} \\
3\end{array}$ & $\begin{array}{l}\mathrm{W} \\
\mathrm{e} \\
\mathrm{e} \\
\mathrm{k} \\
5\end{array}$ & $\begin{array}{l}\text { W } \\
\mathrm{e} \\
\mathrm{e} \\
\mathrm{k} \\
7\end{array}$ & $\begin{array}{l}\mathrm{W} \\
\mathrm{e} \\
\mathrm{e} \\
\mathrm{k} \\
9\end{array}$ & $\begin{array}{l}\mathrm{W} \\
\mathrm{e} \\
\mathrm{e} \\
\mathrm{k} \\
1 \\
1 \\
\end{array}$ & $\begin{array}{l}\mathrm{W} \\
\mathrm{e} \\
\mathrm{e} \\
\mathrm{k} \\
1 \\
3 \\
\end{array}$ & $\begin{array}{l}\mathrm{W} \\
\mathrm{e} \\
\mathrm{e} \\
\mathrm{k} \\
1 \\
5 \\
\end{array}$ & $\begin{array}{l}\text { W } \\
\mathrm{e} \\
\mathrm{e} \\
\mathrm{k} \\
1\end{array}$ & $\begin{array}{l}\mathrm{W} \\
\mathrm{e} \\
\mathrm{e} \\
\mathrm{k} \\
3\end{array}$ & $\begin{array}{l}\text { W } \\
\mathrm{e} \\
\mathrm{e} \\
\mathrm{k} \\
5\end{array}$ & $\begin{array}{l}\mathrm{W} \\
\mathrm{e} \\
\mathrm{e} \\
\mathrm{k} \\
7\end{array}$ & $\begin{array}{l}\text { W } \\
\mathrm{e} \\
\mathrm{e} \\
\mathrm{k} \\
9\end{array}$ & $\begin{array}{l}\mathrm{W} \\
\mathrm{e} \\
\mathrm{e} \\
\mathrm{k} \\
1 \\
1 \\
\end{array}$ & $\begin{array}{l}\mathrm{W} \\
\mathrm{e} \\
\mathrm{e} \\
\mathrm{k} \\
1 \\
3 \\
\end{array}$ & $\begin{array}{l}\mathrm{W} \\
\mathrm{e} \\
\mathrm{e} \\
\mathrm{k} \\
1 \\
5\end{array}$ \\
\hline $\begin{array}{l}\text { Meet with } \\
\text { Preceptor }\end{array}$ & $\mathrm{x}$ & $\mathrm{x}$ & $\mathrm{x}$ & $\mathrm{x}$ & $x$ & $\mathrm{x}$ & $\mathrm{x}$ & $\mathrm{x}$ & $\mathrm{x}$ & $\mathrm{x}$ & $\mathrm{x}$ & $\mathrm{x}$ & $\mathrm{x}$ & $\mathrm{x}$ & $\mathrm{x}$ & $\mathrm{x}$ & $\mathrm{x}$ & $\mathrm{x}$ & $\mathrm{x}$ & $\mathrm{x}$ & $\mathrm{x}$ & $\mathrm{x}$ & $\mathrm{x}$ & $\mathrm{x}$ \\
\hline $\begin{array}{l}\text { Project } \\
\text { approval with } \\
\text { Preceptor and } \\
\text { Advisor }\end{array}$ & & $\mathrm{x}$ & & & & & & & & & & & & & & & & & & & & & & \\
\hline $\begin{array}{l}\text { Discuss plan } \\
\text { with preceptor }\end{array}$ & & $\mathrm{x}$ & & & & & & & & & & & & & & & & & & & & & & \\
\hline $\begin{array}{l}\text { Identify key } \\
\text { stakeholders }\end{array}$ & & & $\mathrm{x}$ & & & & & & & & & & & & & & & & & & & & & \\
\hline $\begin{array}{l}\text { Receive buy- } \\
\text { in from } \\
\text { managers }\end{array}$ & & & $\mathrm{x}$ & & & & & & & & & & & & & & & & & & & & & \\
\hline $\begin{array}{l}\text { Create data } \\
\text { collection tool }\end{array}$ & & & & $\mathrm{x}$ & & & & & & & & & & & & & & & & & & & & \\
\hline $\begin{array}{l}\text { Conduct risk } \\
\text { assessment }\end{array}$ & & & & $\mathrm{x}$ & & & & & & & & & & & & & & & & & & & & \\
\hline $\begin{array}{l}\text { Prepare } \\
\text { budget }\end{array}$ & & & & $\mathrm{x}$ & & & & & & & & & & & & & & & & & & & & \\
\hline $\begin{array}{l}\text { Prepare } \\
\text { project } \\
\text { proposal }\end{array}$ & & & $\mathrm{x}$ & $\mathrm{x}$ & $\mathrm{x}$ & $\mathrm{x}$ & $\mathrm{x}$ & & & & & & & & & & & & & & & & & \\
\hline $\begin{array}{l}\text { Complete } \\
\text { project } \\
\text { proposal }\end{array}$ & & & & & & & & $\mathrm{x}$ & & & & & & & & & & & & & & & & \\
\hline $\begin{array}{l}\text { Meet with key } \\
\text { stakeholders }\end{array}$ & & & & & & & & & $\mathrm{x}$ & & & & & & & & & & & & & & & \\
\hline $\begin{array}{l}\text { Present draft } \\
\text { operating } \\
\text { procedure for } \\
\text { discussion }\end{array}$ & & & & & & & & & $\mathrm{x}$ & & & & & & & & & & & & & & & \\
\hline Finalize & & & & & & & & & & $\mathrm{x}$ & & & & & & & & & & & & & & \\
\hline
\end{tabular}




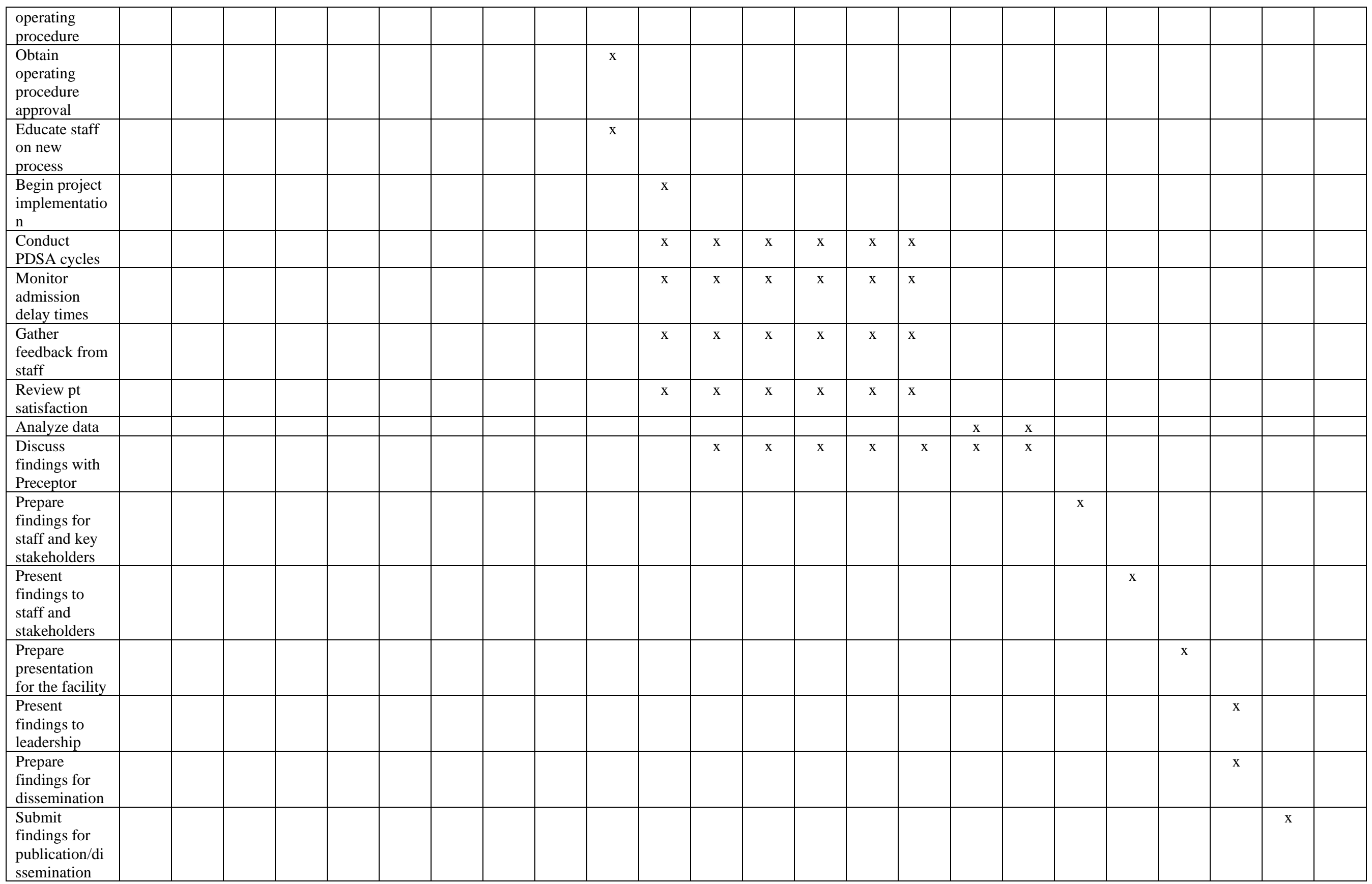


\begin{tabular}{|l|l|}
\hline Submit project & \\
\hline
\end{tabular}

\begin{tabular}{|l|l|l|l|l|l|l|l|l|l|l|}
\hline & & & & & & & & & & \\
\hline
\end{tabular}


Appendix G

Data Collection Tool for Admission (Elapsed Time Data)

\begin{tabular}{|c|c|c|c|c|c|c|c|c|c|c|c|c|c|}
\hline$\frac{\frac{\pi}{0}}{\frac{\pi}{\pi}}$ & Patient & $\begin{array}{l}\text { Presentaion } \\
\text { Date }\end{array}$ & $\begin{array}{l}\text { Presentation } \\
\text { Time }\end{array}$ & $\begin{array}{c}\text { Admission Decision } \\
\text { Time }\end{array}$ & $\begin{array}{c}\text { Call for Bed } \\
\text { Time }\end{array}$ & $\begin{array}{c}\text { Bed Assignment } \\
\text { Time }\end{array}$ & $\begin{array}{c}\text { Notification of } \\
\text { Admisison }\end{array}$ & $\begin{array}{c}\text { Nursing Report } \\
\text { Time }\end{array}$ & $\begin{array}{l}\text { Disposition } \\
\text { Time }\end{array}$ & ED Provider & $\begin{array}{c}\text { Admitting } \\
\text { Provider }\end{array}$ & ED RN & $\begin{array}{l}\text { Admitting } \\
\text { RN }\end{array}$ \\
\hline ר్ & $\begin{array}{l}\text { sequentially } \\
\text { assigned } \\
\text { number }\end{array}$ & $\begin{array}{l}\text { date of ED } \\
\text { presentation }\end{array}$ & $\begin{array}{l}\text { time of ED } \\
\text { presentaiton }\end{array}$ & $\begin{array}{c}\text { time of admisison to Med } \\
\text { Surg }\end{array}$ & $\begin{array}{l}\text { time of ED bed } \\
\text { request }\end{array}$ & $\begin{array}{l}\text { time ED given bed } \\
\text { asssignment by bed } \\
\text { control }\end{array}$ & $\begin{array}{c}\text { time med surg nurse } \\
\text { notified of admission } \\
\text { by bed control }\end{array}$ & $\begin{array}{c}\text { time nursing hand off } \\
\text { complete }\end{array}$ & $\begin{array}{l}\text { time patient } \\
\text { departs ED }\end{array}$ & \begin{tabular}{|c|} 
ED provider \\
admititng patient
\end{tabular} & $\begin{array}{l}\text { accepting } \\
\text { provider }\end{array}$ & $\begin{array}{l}\text { ED nurse } \\
\text { assigned }\end{array}$ & $\begin{array}{l}\text { accepting med } \\
\text { surg nurse }\end{array}$ \\
\hline : & $\begin{array}{l}\text { next available } \\
\text { number on } \\
\text { admission log }\end{array}$ & EDIS & EDIS & $\begin{array}{l}\text { time admission order is } \\
\text { signed in EHR }\end{array}$ & $\begin{array}{c}\text { time documented } \\
\text { on admission log } \\
\text { by bed control }\end{array}$ & $\begin{array}{c}\text { time documented on } \\
\text { admission log by bed } \\
\text { control }\end{array}$ & $\begin{array}{c}\text { time documented on } \\
\text { admission log by bed } \\
\text { control }\end{array}$ & $\begin{array}{c}\text { time of SBAR note in } \\
\text { EHR }\end{array}$ & EDIS & EDIS & EHR & EDIS & EHR \\
\hline 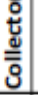 & bed control & bed control & bed control & bed control & bed control & bed control & bed control & bed control & bed control & $\begin{array}{c}\text { project lead } \\
\text { (anonymized) }\end{array}$ & $\begin{array}{c}\text { project lead } \\
\text { (anonymized) }\end{array}$ & $\begin{array}{c}\text { project lead } \\
\text { (anonymized) }\end{array}$ & $\begin{array}{c}\text { project lead } \\
\text { (anonymized) }\end{array}$ \\
\hline & 0 & $7 / 6 / 2020$ & 1325 & 1445 & 1446 & 1450 & 1452 & 1455 & 1505 & $p_{1}$ & $P 2$ & RI & 82 \\
\hline & 1 & & & & & & & & & & & & \\
\hline & 2 & & & & & & & & & & & & \\
\hline & 3 & & & & & & & & & & & & \\
\hline & 4 & & & & & & & & & & & & \\
\hline & 5 & & & & & & & & & & & & \\
\hline & 6 & & & & & & & & & & & & \\
\hline & 7 & & & & & & & & & & & & \\
\hline & 8 & & & & & & & & & & & & \\
\hline & 9 & & & & & & & & & & & & \\
\hline$\underset{\pi}{\mathbb{m}}:$ & & & & & & & & & & & & & \\
\hline a & 11 & & & & & & & & & & & & \\
\hline & 12 & & & & & & & & & & & & \\
\hline & 13 & & & & & & & & & & & & \\
\hline & 14 & & & & & & & & & & & & \\
\hline & 15 & & & & & & & & & & & & \\
\hline & 16 & & & & & & & & & & & & \\
\hline & 17 & & & & & & & & & & & & \\
\hline & 18 & & & & & & & & & & & & \\
\hline & 19 & & & & & & & & & & & & \\
\hline & 20 & & & & & & & & & & & & \\
\hline & & & & & & & & & & & & & \\
\hline
\end{tabular}


Appendix $\mathrm{H}$

Data Collection Tool for Process Data

\begin{tabular}{|r|c|c|c|c|c|c|}
\hline \multicolumn{1}{|c|}{ Date } & Shift & $\begin{array}{c}\text { Bed Ahead } \\
\text { Assigned }\end{array}$ & $\begin{array}{c}\text { Bed Control Notified } \\
\text { within } 30 \text { minutes of } \\
\text { shift change }\end{array}$ & $\begin{array}{c}\text { VOCERA in use } \\
\text { by staff }\end{array}$ & Comments & Charge Nurse Signature \\
\hline Monday & AM & $\mathrm{Y} / \mathrm{N}$ & $\mathrm{Y} / \mathrm{N}$ & $\mathrm{Y} / \mathrm{N}$ & & \\
\hline $8 / 3 / 2020$ & $\mathrm{PM}$ & $\mathrm{Y} / \mathrm{N}$ & $\mathrm{Y} / \mathrm{N}$ & $\mathrm{Y} / \mathrm{N}$ & & \\
\hline Tuesday & $\mathrm{AM}$ & $\mathrm{Y} / \mathrm{N}$ & $\mathrm{Y} / \mathrm{N}$ & $\mathrm{Y} / \mathrm{N}$ & & \\
\hline $8 / 4 / 2020$ & $\mathrm{PM}$ & $\mathrm{Y} / \mathrm{N}$ & $\mathrm{Y} / \mathrm{N}$ & $\mathrm{Y} / \mathrm{N}$ & & \\
\hline Wednesday & $\mathrm{AM}$ & $\mathrm{Y} / \mathrm{N}$ & $\mathrm{Y} / \mathrm{N}$ & $\mathrm{Y} / \mathrm{N}$ & & \\
\hline $8 / 5 / 2020$ & $\mathrm{PM}$ & $\mathrm{Y} / \mathrm{N}$ & $\mathrm{Y} / \mathrm{N}$ & $\mathrm{Y} / \mathrm{N}$ & & \\
\hline Thursday & $\mathrm{AM}$ & $\mathrm{Y} / \mathrm{N}$ & $\mathrm{Y} / \mathrm{N}$ & $\mathrm{Y} / \mathrm{N}$ & & \\
\hline $8 / 6 / 2020$ & $\mathrm{PM}$ & $\mathrm{Y} / \mathrm{N}$ & $\mathrm{Y} / \mathrm{N}$ & $\mathrm{Y} / \mathrm{N}$ & & \\
\hline Friday & $\mathrm{AM}$ & $\mathrm{Y} / \mathrm{N}$ & $\mathrm{Y} / \mathrm{N}$ & $\mathrm{Y} / \mathrm{N}$ & & \\
\hline $8 / 7 / 2020$ & $\mathrm{PM}$ & $\mathrm{Y} / \mathrm{N}$ & $\mathrm{Y} / \mathrm{N}$ & $\mathrm{Y} / \mathrm{N}$ & & \\
\hline Saturday & $\mathrm{AM}$ & $\mathrm{Y} / \mathrm{N}$ & $\mathrm{Y} / \mathrm{N}$ & $\mathrm{Y} / \mathrm{N}$ & & \\
\hline $8 / 8 / 2020$ & $\mathrm{PM}$ & $\mathrm{Y} / \mathrm{N}$ & $\mathrm{Y} / \mathrm{N}$ & $\mathrm{Y} / \mathrm{N}$ & & \\
\hline Sunday & $\mathrm{AM}$ & $\mathrm{Y} / \mathrm{N}$ & $\mathrm{Y} / \mathrm{N}$ & $\mathrm{Y} / \mathrm{N}$ & & \\
\hline $8 / 9 / 2020$ & $\mathrm{PM}$ & $\mathrm{Y} / \mathrm{N}$ & $\mathrm{Y} / \mathrm{N}$ & $\mathrm{Y} / \mathrm{N}$ & & \\
\hline
\end{tabular}

